\title{
EROSÃO HÍDRICA NA ALTA BACIA DO RIO ARAGUAIA: DISTRIBUIÇÃO, CONDICIONANTES, ORIGEM E DINÂMICA ATUAL
}

\author{
Selma Simões de Castro
}

\begin{abstract}
RESUMO: Apresentam-se resultados de dois programas de pesquisa desenvolvidos sobre erosão hídrica no Setor Sul da Alta Bacia do Rio Araguaia, situada na região Centro-Oeste, no Planalto Setentrional da Bacia Sedimentar do Paraná, intensamente desmatado e que contém remanescentes do bioma Cerrado, um dos hotspots do planeta. Tais programas foram desenvolvidos em multi-escalas e, na escala regional, permitiram identificar as áreas mais críticas onde foram desenvolvidos estudos de detalhe. Constatou-se que as voçorocas se concentram na superfície rebaixada dissecada e suavizada que contorna a superfície cimeira, conhecida como Chapada, nível de recarga do aqüífero regional, separadas por zona escarpada. A superfície rebaixada relaciona-se aos solos arenosos finos derivados da Formação Botucatu e os focos se situam tanto nas amplas cabeceiras de drenagem concavizadas dos tributários do rio Araguaia, em prolongamento dos seus canais, como perpendicularmente a eles, sobretudo nas porções alta e média das sub-bacias, nos segmentos finais das vertentes também concavizados e mais declivosos, inclusive do próprio rio Araguaia, onde ocorrem as maiores voçorocas da região. Duas áreas dentre as mais críticas são focadas neste artigo para ilustrar o fenômeno, onde os estudos foram feitos com base em levantamentos de solos, inclusive em toposseqüências, acompanhados de análises laboratoriais, de ensaios de infiltração e de condutividade hidráulica e de monitoramentos de chuvas e do lençol freático por piezometria durante três anos e métodos geofísicos. Os resultados evidenciam relações entre os focos erosivos, os solos, o substrato geológico, a forma das vertentes, o uso dos solos, as chuvas e os fluxos hídricos superficiais e subsuperficiais e enfatizam que o processo de voçorocamento resulta de suscetibilidade ao processo e de um desequilibrio hidropedológico que afeta, sobretudo, a base das vertentes. 0 desmatamento indiscriminado, o elevado gradiente hidráulico e o risco de convergência dos escoamentos superficial e subsuperficial intensificados para a zona de saturação, principalmente ao fim da estação chuvosa, são capazes de promover fluxos hídricos intensos e de alta energia. $\mathrm{O}$ voçorocamento caracteriza-se por evolução remontante na vertente e associado à ação de piping, controlado por direções estruturais dominantes. Ao final é apresentada uma proposta de recomposição ambiental para a área das nascentes do rio Araguaia, com base nas leis ambientais, em práticas conservacionistas e em recuperação de reservas legais e de áreas de preservação permanente degradadas.
\end{abstract}

Palavras-chave: Alta Bacia do rio Araguaia, erosão hídrica, suscetibilidade, riscos, uso e manejo das terras, monitoramento hidrológico, desequilíbrio hidropedológico.

\section{Introdução}

O rio Araguaia é um dos grandes rios do país, cuja bacia drena áreas de vários estados, destacando-se Goiás e Mato Grosso para a alta e média bacia, e que ainda contam com fragmentos importantes do bioma Cerrado, um dos hotspots do planeta. A Alta Bacia do Rio Araguaia, com $4496 \mathrm{~km}^{2}$, situa-se na região centro-oeste do país, e relaciona-se ao Planalto Setentrional da Bacia Sedimentar do Paraná (FRANCO e PINHEI$R O, 1982)$. Ela vem sofrendo transformação intensa de usos desde meados do século passado pela fronteira agrícola com a ocupação rápida do bioma. Tem ocorrido a substituição de extensas áreas do Cerrado por atividades agropecuárias voltadas à exportação. Tal ocupação iniciou-se na década de 1970 e foi facilitada por programas governamentais do II Plano Nacional de Desenvolvimento (BRASIL, 1974). Especificamente o Polocentro (Programa de Desenvolvimento do Cerrado), implementado em 1975, promoveu a sua incorporação ao sistema produtivo à custa de desmatamento intenso e indiscriminado que substituiu total- mente cerca da metade da cobertura original por atividades ditas modernas e relacionadas à chamada Revolução Verde. Fortemente motomecanizadas e em insumos agrícolas, especializaram-se no cultivo de grãos, sobretudo soja e milho, além de algodão, e na pecuária de corte (GOEDERT e WAGNER, 2004; GOMES e TEIXEIRA NETO, 2004), entretanto, sem adoção ampla e generalizada de práticas conservacionistas (CASTRO et al., 2004). Consultando os quatro últimos censos agropecuários do IBGE, desde 1960, para a produção de lenha, soja e milho em alguns municípios da alta bacia, como 0 de Mineiros e de Alto Taquari, por exemplo, constata-se aumento notável na produção, a partir de 1980 (MAGNOLI e ARAÚJO, 1992, dentre outros).

A degradação decorrente desse processo, além de ter comprometido a biodiversidade em conseqüência dos impactos relacionados aos desmatamentos, à retirada não seletiva de madeira para carvão e outros, ao isolamento dos fragmentos remanescentes, ao descumprimento das leis ambientais, sobretudo quanto às reservas legais e áreas de preservação 
permanente, à contaminação de solos e águas por corretivos, fertilizantes e biocidas em geral, que persistem até os dias atuais, também gerou impactos erosivos e de assoreamento, particularmente no setor sul da alta bacia do rio Araguaia, onde se localiza a região popularmente conhecida como das nascentes, pela antiga polêmica a respeito de serem duas possíveis (denominadas A e B).

O Setor Sul da Alta Bacia do rio Araguaia, excluída a subbacia do rio Babilônia, abrange uma área com pouco mais de $1500 \mathrm{~km}^{2}$, cuja zona dissecada e rebaixada que envolve a superfície cimeira conhecida como Chapada, nível elevado de recarga do aqüifero regional que abastece as bacias do Paraná e do Araguaia, denominado de Cumeeira do Brasil (FEMAS, 1998a), concentra a maioria quase absoluta dos focos erosivos lineares, de médio até grande porte, todos interpretados como voçorocas, com base na definição do IPT (1990).

Observações de fotos aéreas da área na escala 1:60000 da década de 1960 (USAF, 1966) permitem constatar que apenas 12 focos eram visíveis, porém, mais de 90 voçorocas de médio e grande porte foram reconhecidas com imagens de satélite do final da década de 1990, na mesma escala, concentradas principalmente em áreas de pastagem (53 do total) e secundariamente, em áreas agrícolas (33), sendo 23 de grande porte (300 a $4000 \mathrm{~m}$ de ramo principal), surgidos principalmente nos primeiros anos da década de 1980, hoje, na maioria, com mais que $1000 \mathrm{~m}$ no ramo principal; e o restante de porte médio (68), em geral mais recentes (SILVA, BARBALHO e CASTRO et al., 2001; BARBALHO, SILVA e CASTRO, 2001; CAMPOS e BARBALHO, 2001; CASTRO et al., 2004).

Diversas equipes de pesquisadores e técnicos se debruçaram sobre a área, destacam-se dois grandes programas que agruparam vários projetos, aqui identificados como: Programa 1 "Programa de Desenvolvimento da Alta Bacia do Rio Araguaia" com dois projetos - "Bacia do Alto Araguaia: Diagnóstico e prognóstico dos processos Erosivos, análise de suas conseqüências e propostas de controle", financiado pela Secretaria de Ciência e Tecnologia do Estado de Goiás CONCITEG Processo 16500920 (CASTRO, 2000) e "Diagnóstico, prognóstico e controle de processos erosivos lineares em áreas urbanas e rurais dos estados de Mato Grosso e Goiás", financiado pelo CNPq Processo 52869990 (CASTRO, 2002a) e FAPESP Fundação de Amparo à Pesquisa do Estado de São Paulo Processo 2000/04455-2 (CASTRO, 2002b); Programa 2 de "Recomposição das Nascentes do Araguaia" (FEMAS, 1998b), financiado pelo Ministério do Meio Ambiente (Decreto 5079/28-06-
99), através da Secretaria de Meio Ambiente e Recursos Hídricos do Estado de Goiás, que contou com várias assessorias especializadas e foi finalizado no âmbito do Instituto de Estudos Sócio-Ambientais (IESA) da Universidade Federal de Goiás (UFG) (CASTRO, XAVIER e BARBALHO, 2004; CASTRO, XAVIER e MACEDO, no prelo).

O objetivo deste artigo é apresentar os principais dados relativos aos condicionantes da origem, evolução e da dinâmica atual dos focos erosivos hídricos, obtidos nos dois programas citados e nas duas áreas selecionadas para ilustrar o fenômeno, a área das nascentes propriamente dita e a área dominada amplamente pela sub-bacia do córrego Queixada, bem como fornecer um exemplo de proposta de recomposição ambiental da primeira área, alvo principal do Projeto 2.

\section{Materiais e Métodos}

Inicialmente apresenta-se um resumo dos métodos e principais produtos elaborados nos dois projetos citados, detalhando-se aqueles que enfatizam os dois exemplos selecionados para este artigo.

\section{Programa 1}

Caracterizou-se por abordagem multi-escalar (VELDCAMP, 2000), por aproximações sucessivas, inspiradas em Ab'SABER (1969), elaborando-se vários mapas de base e de síntese, tais como: localização georreferenciada (Landsat TM5, 1999 + Spring); distribuição de focos erosivos por restituição desta mesma imagem e da imagem Landsat ETM7+ (2003) atualizada em campo; geologia (litologias e lineamentos estruturais) por fotointerpretação e controle de campo (CAMPOS et al., 2000); geomorfologia (superfícies geomórficas, feições morfológicas do modelado, em especial das concavidades) por fotointerpretação apoiada em bibliografia de referência, de declividades sobre a base topográfica (DE BIASI, 1992), e de hipsometria idem (LIBAULT, 1968); de solos e seu uso em 1966, 1999 e 2003 por fotointerpretação usual e com imagens de satélite LANDSAT (1999, 2003) tratadas no Spring e de clima, com ênfase nas chuvas, em particular nas intensidades, duração e freqüência dos episódios, com base em registros pluviométricos de oito estações da CPRM (Comissão Geológica do Brasil) e dados do SIMEGO (Sistema Meteorológico de Goiás), e de dados pluviográficos de duas estações (Fazenda Taquari e Fazenda Paraíso), baseandose nas metodologias de BOIN (2000) e na classificação proposta por REICHARDT (1987) (RAMOS e CASTRO, 2003); capacidade de uso das terras (LEPSCH et al., 1991), discrepâncias entre 
capacidade de uso e uso atual por correlação espacial; compartimentação morfopedológica (CASTRO e SALOMÃO, 2000), suscetibilidade e riscos à erosão laminar e linear (SALOMÃO, 1999). Foram realizados levantamentos detalhados de solos em toposseqüência (BOULET, 1988) na vertente do córrego Capivara e monitoramento da chuva por métodos pluviométricos e pluviográficos e do lençol freático por piezometria (MARINHO e CASTRO, 2003a e b), ao longo de três anos hidrológicos, e por métodos geofísicos (SHIRAIWA e MOURA, 2002) em uma vertente do córrego Capivara, integrante da subbacia do córrego Queixada, situada a leste da alta bacia do Araguaia.

Várias publicações resultaram desses estudos, dentre elas: BARBALHO (2002); BARBALHO et al. (2001, 2002); BARBALHO e CASTRO (2003); BARBALHO e CAMPOS (2001); CAMPOS et al. (2000); CASTRO, XAVIER e BARBALHO (2004); CASTRO (2000, 2002a e b); CASTRO et al. (2004); FARIA (2001); MEDEIROS e CASTRO (2002); OLIVEIRA e CASTRO (2005); REZENDE (2003); SILVA, BARBALHO e CASTRO (2001); RAMOS e CASTRO (2003); XAVIER e CASTRO (2005).

Tais estudos revelaram expressiva concentração dos focos erosivos na zona rebaixada que contorna a superfície cimeira regional (Serra de Caiapó), em solos arenosos finos (Neossolos Quartzarênicos, antes denominados de Areias Quartzosas) derivados da Formação Botucatu. Estes solos estão relacionados a vertentes suaves e longas $(700$ a $3500 \mathrm{~m}$ ) predominantemente ocupadas por pastagens e secundariamente por agricultura. Atividades relacionadas às grandes propriedades rurais onde é freqüente 0 descumprimento da legislação ambiental no que tange às áreas de preservação permanente e reserva legal. Também há insuficiência ou inadequação de práticas conservacionistas e, não raro, superpastoreio. Constatou-se também que os focos de médio porte e menores se concentram nas amplas cabeceiras de drenagem concavizadas dos tributários do rio Araguaia, principalmente de 1- a 3- ordem do lado goiano, em vertentes longas (700 a mais de $3000 \mathrm{~m}$ ) e declives de até $12 \%$, posicionadas em setores côncavos e declivosos (12\%) perpendiculares aos canais relativamente encaixados. Os maiores, entretanto, localizam-se diretamente conectados ao rio Araguaia e predominam do lado mato-grossense, igualmente em setores basais concavizados das vertentes. Permitiram, ainda, identificar as zonas com maior suscetibilidade e risco (XAVIER e CASTRO, 2005), a concentração dos focos erosivos lineares e elevados riscos ao fenômeno (BARBALHO e CASTRO, 2002) em quatro compartimentos morfopedológicos, dentre eles, a área das nascentes propriamente dita e a área dominada pela bacia do córrego Queixada situada a leste da alta bacia (CASTRO et al., 2004), além de quatro outras áreas com elevados riscos à erosão laminar (OLIVEIRA e CASTRO, 2005), os quais revelam certa correspondência espacial com as áreas de risco à erosão linear.

O comportamento físico-hídrico de solos e vertente, enfatizado neste artigo, realizado em escala de detalhe e focando uma vertente do córrego Capivara como já relatado, baseou-se: (a) no monitoramento de chuvas durante 3 anos; (b) no monitoramento do lençol freático através de uma estação de piezômetros (27 poços) durante 3 anos hidrológicos, com base nas instruções de SALOMÃO (1999) e em perfis geofísicos com GPR (Radar de Penetração no Solo) nas estações seca e chuvosa e SEV (Sondagem Elétrica Vertical) na estação seca, cujos resultados foram correlacionados no tempo e no espaço; (c) em estudo detalhado dos solos com levantamento em toposseqüência (BOULET, 1988; CASTRO, 1987, 2002; CASTRO et al., 2004), acompanhados de análise físicas e químicas de amostras; (d) no cadastro em campo (modelo de cadastro do IPT, 1986) de um dos focos mais recentes da área, disposto perpendicularmente ao córrego Capivara próximo à sua confluência com o córrego Queixada, denominado de voçoroca Paraíso, acompanhado de observação, medição e descrição estratigráfica de seus taludes inferiores, de medidas de orientação no arenito, saprólito, solos e depósitos com bússola e de medidas de vazão, e de monitoramento de evolução em dois anos, por estacas. Várias publicações dessa etapa merecem destaque, dentre elas: MARINHO e CASTRO, 2003a e b; CASTRO et al. (2004), CASTRO e RAMOS (2003) e REZENDE (2003).

Em síntese, a combinação entre chuvas intensas e concentradas no verão (ASSAD, ASSAD e EVANGELISTA, 1994; NIMER, 1989; RAMOS e CASTRO, 2003) que caracterizam a área, de elevada erosividade (BERTONI e LOMBARDI NETO, 1993), com os solos arenosos finos de elevada erodibilidade, principalmente quando mal manejados, parecem ser os responsáveis pela indução dos fenômenos erosivos (SALOMÃO, 1999; CASTRO et al., 2004; OLIVEIRA e CASTRO, 2005).

\section{Programa 2}

Os estudos iniciaram-se pelo cadastro dos maiores focos erosivos da alta bacia (IPT, 1998; CELG, 1998) e prosseguiram com levantamentos detalhados da pequena área das nascentes no extremo sul da alta bacia, com aproximadamente $300 \mathrm{~km}^{2}$, onde se concentra grande número de voçorocas, selecionada por critérios comunitários, pela proximidade com o Parque Nacional 
das Emas e por integrar o então futuro projeto do corredor Emas Taquari. Destacam-se: a delimitação georreferenciada da áreaalvo, o levantamento e cadastro das propriedades rurais, o cadastro detalhado de uma das maiores voçorocas da região (conhecida como Chitolina) (TERRACARTA, 2001a, b) e dos solos de seu entorno, também através de três toposseqüências, incluindo a infiltrometria em campo em uma delas, acompanhados de análises laboratoriais de amostras de solos e ensaios de condutividade hidráulica saturada (BOULET, 2001). Dentre os principais mapas elaborados, destacam-se o mapa de uso do solo (2000) com base em imagem de satélite TM5 (2000), o de delimitação de três áreas por graus decrescentes de prioridade para execução das medidas de controle necessárias $(A, B$ e $C)$, o bloco diagrama da erosão Chitolina e as respectivas seções topográficas e o mapa topográfico da vertente da Chitolina, ambos com base geodésica de precisão (TERRACARTA, 2001). Além dos relatórios técnicos (BOULET, 2001, partes I e II), merecem destaque duas publicações (GOMES et al., 1999; GOMES, CERDEIRA e FILIZOLA, 1999; GOMES et al., 2000).

A convite da SEMARH-GO, uma equipe do IESA da UFG completou os seguintes mapas temáticos do meio físico dessa área: geologia, hipsometria, declividades, concavidades, clima, solos e seus usos em 1966, 1976 e 1999; suscetibilidade e risco à erosão linear; compartimentação morfopedológica; capacidade de uso da terra; discrepância entre a capacidade de uso e o uso atual; aptidão agrícola das terras (RAMALHO e BEEK, 1995) e manejo atual por levantamento em campo lançando os focos erosivos em todos eles (CASTRO, XAVIER e BARBALHO, 2004). Procederam à síntese da correlação espacial entre os focos e os atributos do meio físico e retrabalharam os dados das erosões cadastradas pelo CELG (1998) e, em especial, da voçoroca Chitolina (TERRACARTA, 2001) e, por fim, organizaram e completaram o dossiê de cada propriedade rural (TERRACARTA, 2001), visando estabelecer os déficits de áreas de preservação permanente, de reservas legais e de práticas conservacionistas, de modo a subsidiar as ações para recomposição ambiental da área. Ao final, com base nesses dados, elaborou o Atlas Geoambiental (CASTRO, XAVIER e BARBALHO, 2004) e o Plano Diretor para Controle da Erosão (CASTRO, XAVIER e MACEDO, no prelo), este contendo o mapa e o memorial explicativo da proposta final (GUIMARÃES, 2003) para recomposição da área com base na legislação ambiental dos dois estados (GO, MT), nos indicadores pedológicos e hidrológicos obtidos no monitoramento do Projeto 1 e 2 (incluindo os ensaios de condutividade hidráulica saturada), nos dados ambientais dos cadastros das propriedades rurais e respectivo manejo, à luz dos princípios de corredores de biodiversidade. A seguir, são apresentados os principais métodos adotados, a síntese das duas áreas e discutidos os resultados mais significativos para ilustrar.

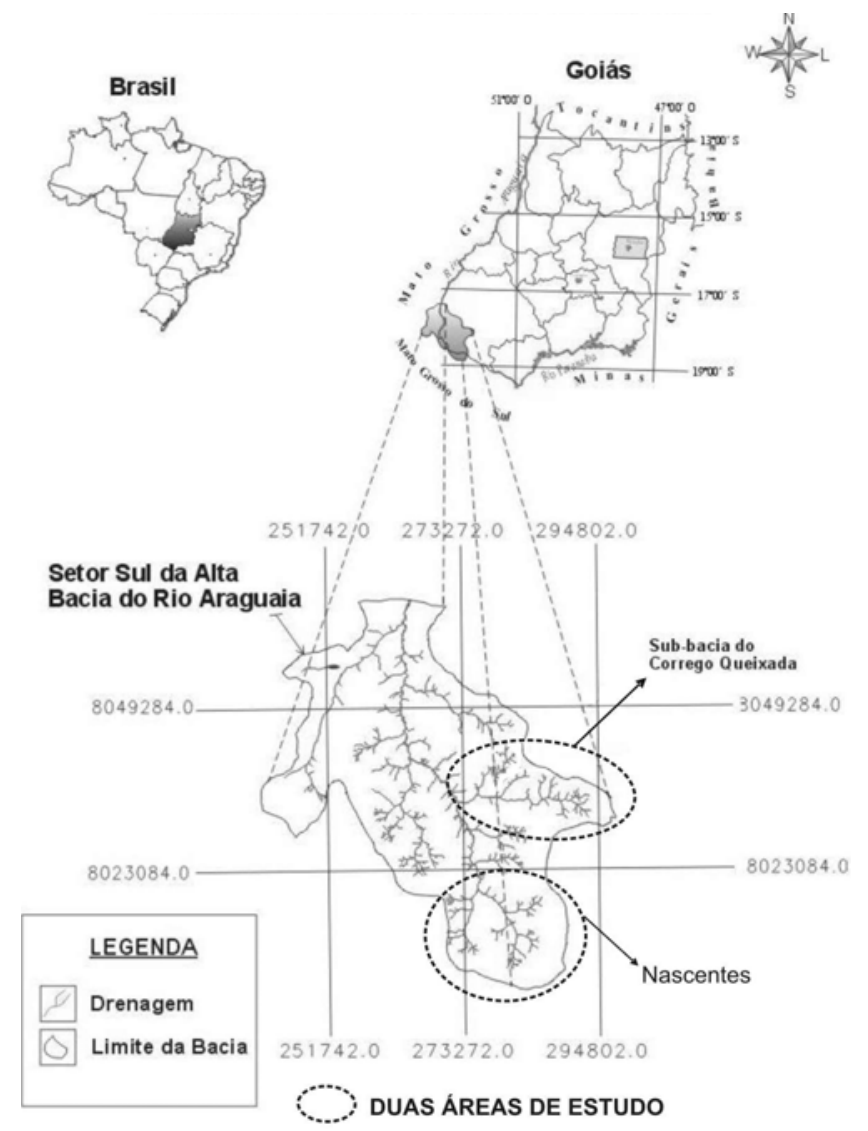

Figura 1 Localização do Setor Sul da Alta Bacia do rio Araguaia indicando as duas áreas onde foram realizadas as pesquisas de detalhe.

\section{RESULTADOS E DISCUSSÕES}

\section{O Setor Sul da Alta Bacia do rio Araguaia - contexto do problema erosivo}

O Setor Sul da Alta Bacia do rio Araguaia é apresentado na Figura 1 onde as duas áreas críticas estão indicadas, além da rede de drenagem e a distribuição dos focos erosivos lineares registrados na escala adotada (1:60000). Note-se que as erosões de grande porte podem atingir mais de $3000 \mathrm{~m}$ de extensão, na maioria, diretamente conectados ao próprio rio Araguaia, o qual, na área, segue grosso modo a direção geral SE-NW e depois inflete para S-N, sendo que seus principais tributários seguem direções praticamente ortogonais a essas. Tal direção está corre- 
lacionada a falhamento presente na Formação Botucatu e as secundárias compõem o sistema de fraturas (DRAGO, 1983). CAMPOS et al. (2000), correlacionando os focos erosivos com os lineamentos estruturais da área, constataram que as mesmas se situam em pontos de cruzamento das direções estruturais dominantes (NW-SE e NE-SW).

Tabela 1 Área e focos erosivos lineares em função do tipo de uso e ocupação da terra (BARBALHO et al., 2001).

\begin{tabular}{|l|r|r|c|r|}
\hline \multirow{2}{*}{ Ocupação da terra } & \multicolumn{2}{|l|}{ Área } & \multicolumn{2}{|c|}{ Focos erosivos lineares } \\
\cline { 2 - 5 } & $\mathbf{\mathbf { k m } ^ { 2 }}$ & $\mathbf{( \% )}$ & $\mathbf{n} \mathbf{0}$ & $\mathbf{( \% )}$ \\
\hline Mata ciliar & 120,00 & 7,91 & 0 & 0,00 \\
\hline Campo úmido & 32,99 & 2,18 & 0 & 0,00 \\
\hline Cerrado denso & 268,78 & 17,72 & 3 & 3,30 \\
\hline Cerrado ralo & 248,78 & 16,39 & 3 & 3,30 \\
\hline Agricultura & 509,63 & 33,60 & 33 & 36,36 \\
\hline Pastagem & 334,43 & 22,05 & 52 & 57,14 \\
\hline Cidade & 2,26 & 0,15 & & \\
\hline Total & $\mathbf{1 5 1 6 , 7 1}$ & $\mathbf{1 0 0 , 0 0}$ & $\mathbf{9 1}$ & $\mathbf{1 0 0 , 0 0}$ \\
\hline
\end{tabular}

Resumidamente, a área caracteriza-se por: (1) uma superfície mais elevada aplainada correspondente à Chapada com mais de $875 \mathrm{~m}$ de altitude, conhecida principalmente como Serra de Caiapó, de baixos declives, em geral menos de 3\%, e baixa densidade de drenagem, sustentada por sedimentos inconsolida-
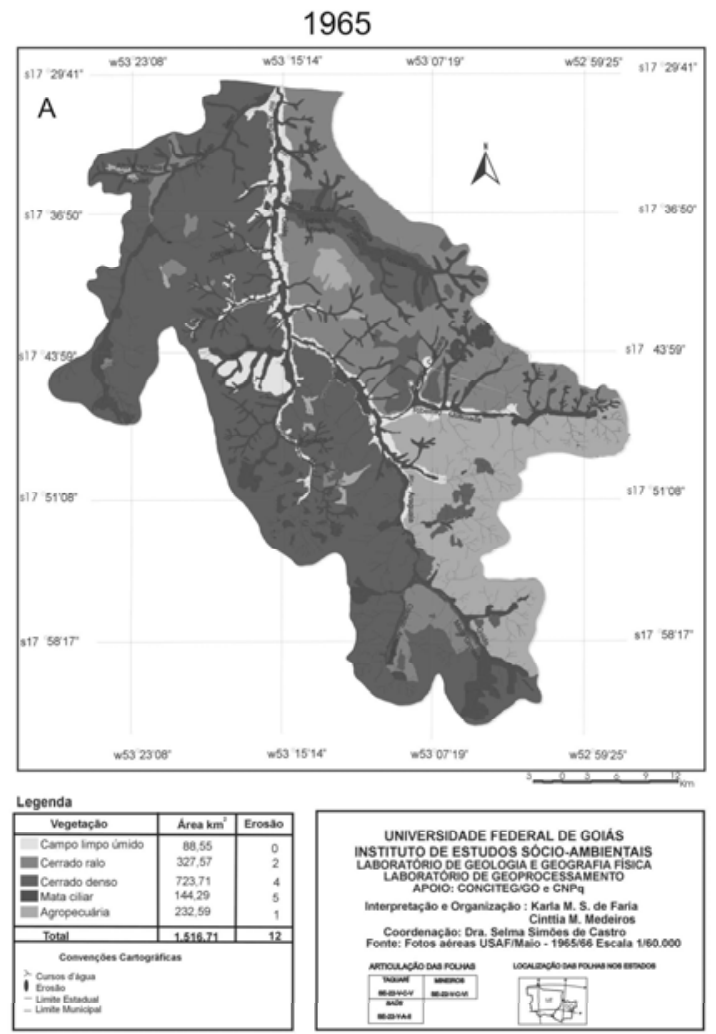

Figura 2 Uso do solo em 1965 (a) e 1999 (b). Fonte: FARIA e MEDEIROS (2001), BARBALHO e CASTRO (2003). dos pós-cretácicos, Terço-Quaternários, correlacionados aos espessos Latossolos Vermelhos, depositados sobre pacote arenítico do Grupo Bauru (Cretáceo) e da Formação Botucatu (JuraTriássico), intercalada por basaltos da Formação Serra Geral (EoCretáceo) (DRAGO, 1983; MAMEDE et al., 1983; NOVAES et al., 1983) correspondendo a quase metade da área das nascentes e menos na área da bacia do córrego Queixada; apresenta prolongamentos ligeiramente rebaixados, semelhantes a ombreiras alongadas onde se desenvolvem os Latossolos Vermelho-Amarelos, por vezes com níveis concrecionários, principalmente na área das nascentes do rio Araguaia; é onde dominam a agricultura intensiva voltada à produção de grãos em geral e as grandes propriedades rurais, freqüentemente sem reservas legais e tampouco sem a faixa de preservação permanente em suas bordas conforme determina a legislação ambiental, de no mínimo $100 \mathrm{~m}$ de recuo; (2) uma zona escarpada e festonada, por vezes desdobrada em níveis escalonados, com declives médios de $25 \%$ a $45 \%$, e um desnível médio de $50 \mathrm{~m}$; desenvolve-se sobre estas duas últimas Formações os Cambissolos, Neossolos Litólicos e afloramentos de rocha; não raro, apresenta cachoeiras e movimentos de massa (quando desmatada), situação comum desde quando era destinada a pastagens extensivas na década de 1980;

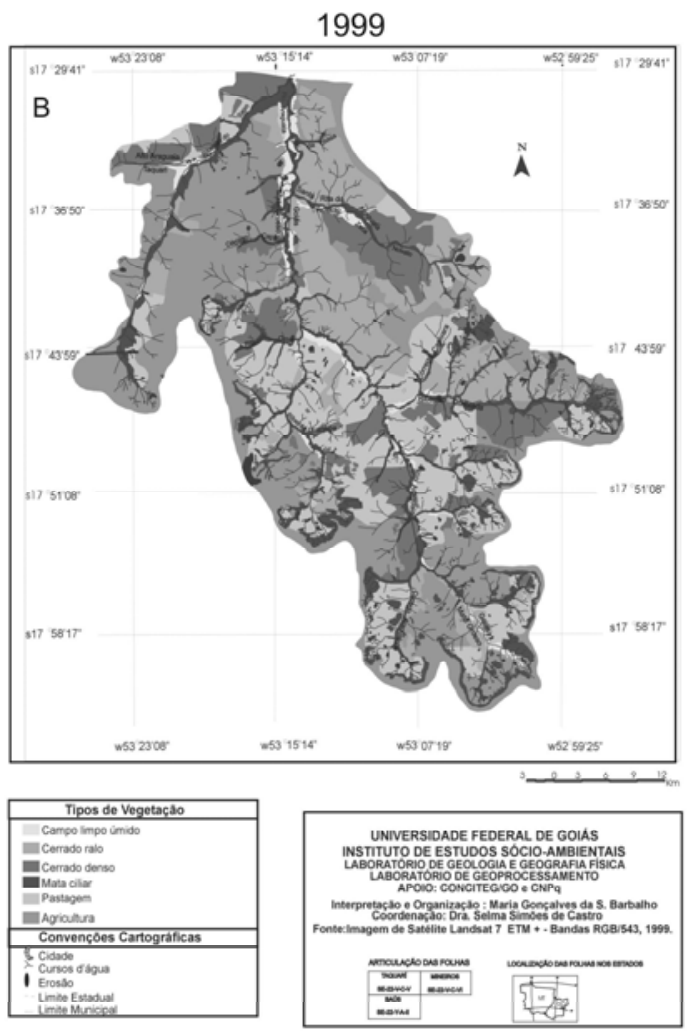


(3) uma superfície dissecada com altitudes que variam de 675 a $825 \mathrm{~m}$, em média, denominada de zona rebaixada, com interflúvios de topos amplos e vertentes longas (mais de $700 \mathrm{a}$ mais de $3000 \mathrm{~m}$ ), baixos declives, em geral menores que $8 \%$, podendo chegar à cerca de $12 \%$ nos segmentos inferiores concavizados ou nas áreas de contribuição das cabeceiras de drenagem de $1^{a}$ a $3^{a}$ ordens, ambos de baixa densidade de drenagem, em geral paralela a dendrítica de baixa densidade, exceto quando as cabeceiras de drenagem se encontram próximas da zona escarpada ou mesmo a ultrapassam, alojando-se nas bordas da Chapada onde são dendríticas de maior densidade; esta superfície é mais expressiva na bacia do Córrego Queixada e menos na área das nascentes em termos das áreas totais. Nesta superfície dominam os espessos Neossolos Quartzarênicos órticos distróficos a álicos (EMBRAPA, 1999) derivados da Formação Botucatu. Nos segmentos inferiores mais declivosos das vertentes, bem como nas amplas cabeceiras de drenagem concavizadas dos topos e terços médios dos amplos interflúvios

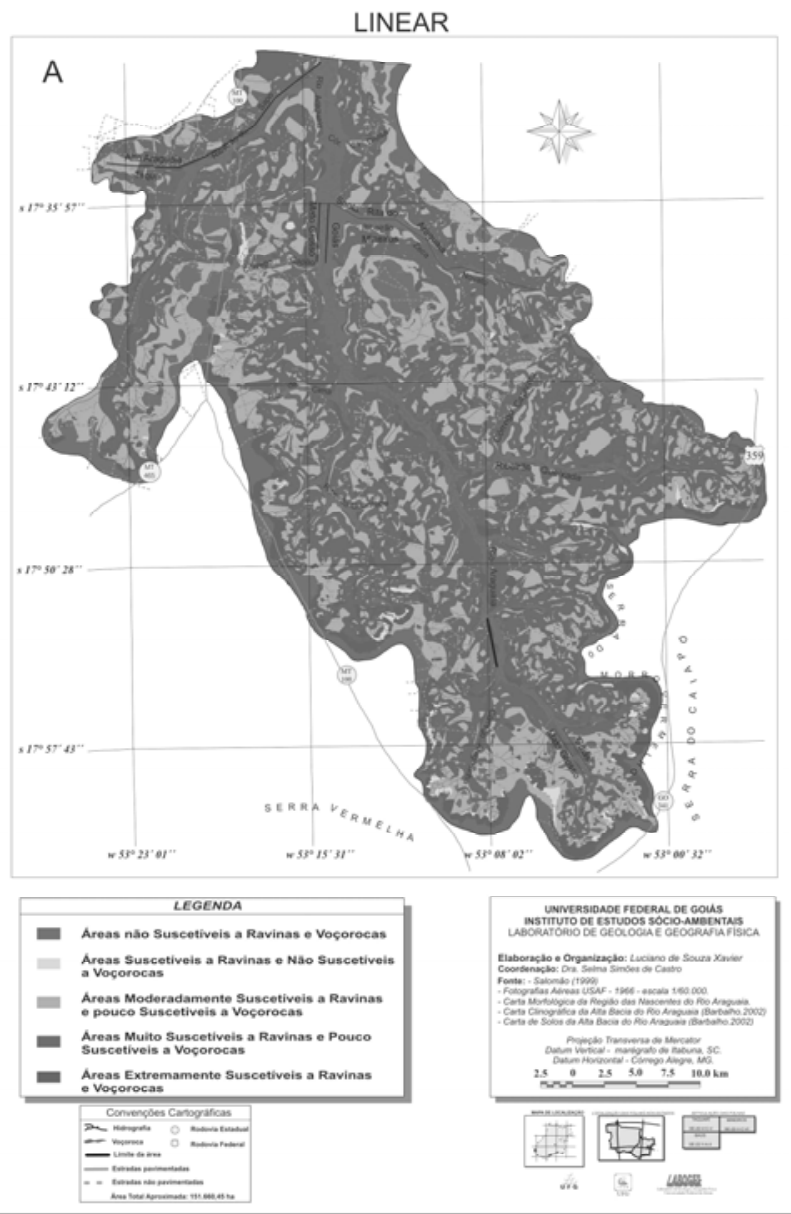

dominam os Neossolos Quartzarênicos hidromórficos e nos fundos de vale embaciados e várzeas restritas, os Gleissolos, comumente distróficos, em geral Melânicos, podendo apresentar horizontes hísticos (NOVAES, 1983; BOULET, 2001; MARINHO e CASTRO, 2003a, b; CASTRO et al., 2004). Constata-se predominância das voçorocas nos Neossolos Quartzarênicos hidromórficos apenas em escala de detalhe, as quais quando remontam as vertentes acabam por atingir os Neossolos Quartzarênicos órticos. Ao descarregarem sedimentos nos fundos de vale podem soterrar os Gleissolos e até mesmo desviar o curso do próprio rio Araguaia (CASTRO et al., 2004), via de regra, com pastagens e raramente com cobertura original, em geral, degradada.

Os compartimentos morfopedológicos e sua suscetibilidade erosiva revelaram que os compartimentos V, VI (correspondentes à área das nascentes do Araguaia), o VII (lado goiano, dominado pelo Córrego Queixada) e o IV (lado mato-grossense, acompanhando o canal do rio Araguaia) são os mais críticos (BARBALHO e CASTRO, 2003).

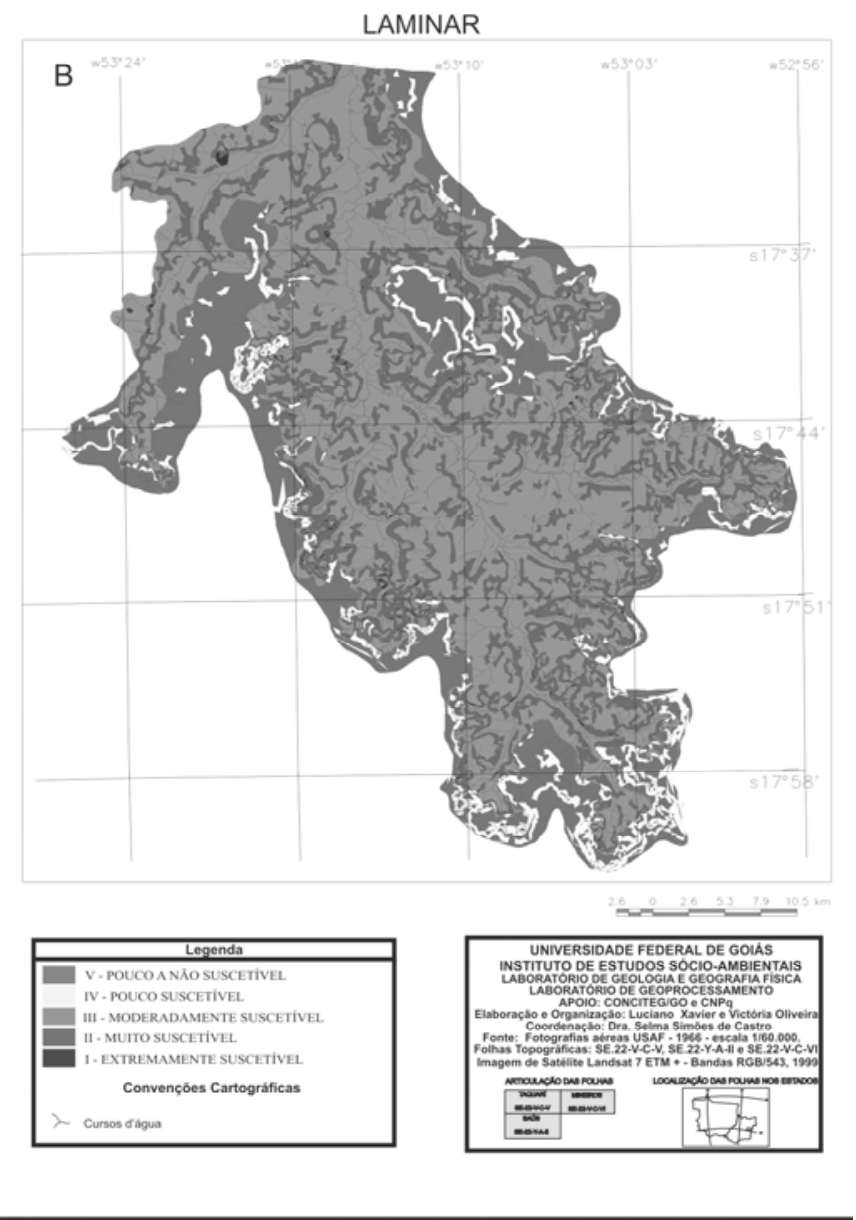

Figura 3 Suscetibilidade a Erosão Linear e Laminar. Fonte: XAVIER e CASTRO (2005), OLIVEIRA e CASTRO (2005). 
A Fig. 2, relativa ao uso do solo, mostra que de 1965 a 2003 houve uma taxa de desmatamento superior a $60 \%$, para 0 total da alta bacia do rio Araguaia. A Tab. 1 resume a situação recente (1999), obtida por geoprocessamento da imagem Landsat TM5 com validação em campo. As suscetibilidades erosivas hídricas, tanto a linear como a laminar, no conjunto da área são mostradas na Fig. 3 a (erosão linear) e 3 b (erosão laminar). Percebe-se 0 moderado a elevado grau de suscetibilidade (natureza arenosa fina com baixo grau de coesão dos solos) das vertentes longas e suaves, com declive ao redor de $8 \%$ e baixo desnível altimétrico $(\sim 50 \mathrm{~m})$, conhecidas como rampas longas (700 a $3500 \mathrm{~m}$ ), que imprimem alta energia ao escoamento superficial (CASTRO e XAVIER, 2005; OLIVEIRA e CASTRO, 2005). Note-se que nas cabeceiras de drenagem e nos fundos de vale as suscetibilidades são maiores.

Comparando-se a discrepância entre a capacidade de uso e o uso atual das terras, nota-se que as voçorocas concentram-se sobretudo em áreas com alta e máxima discrepância. Os graus de (a) LINEAR

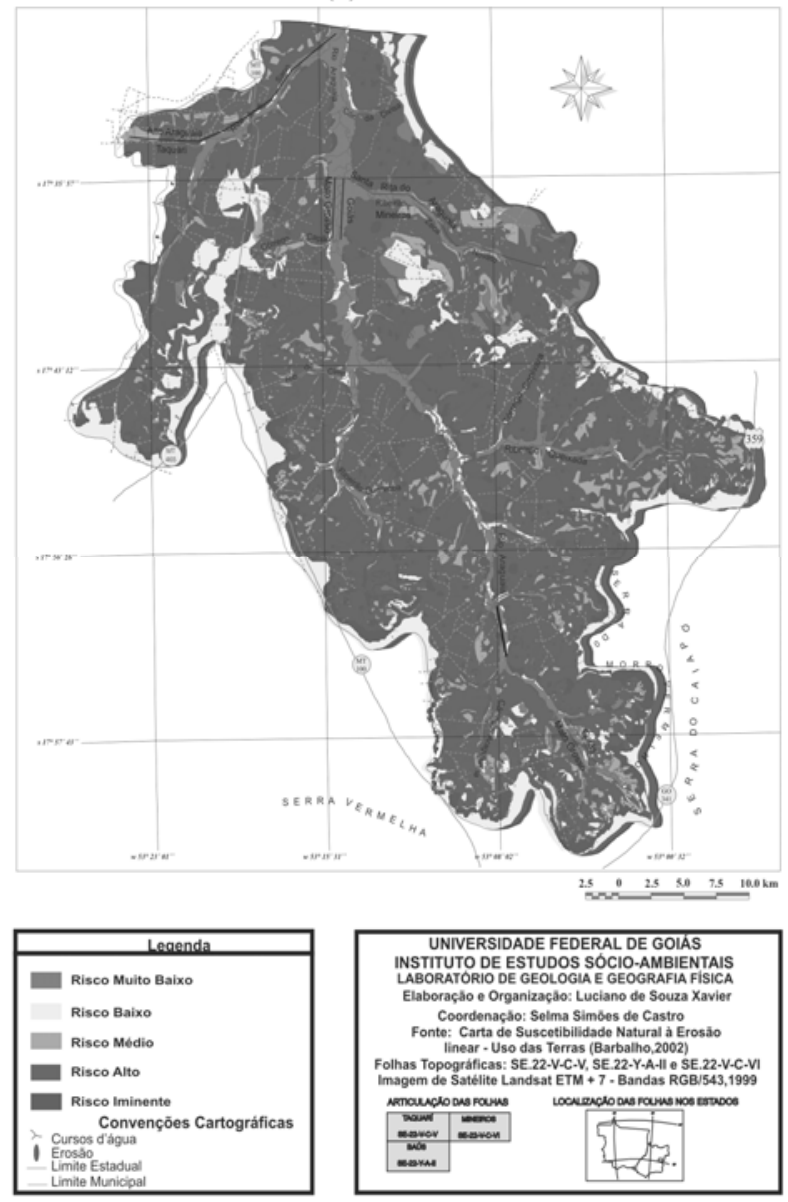

risco à erosão linear e laminar são apresentados nas Fig. 4a e 4b, respectivamente. Os focos erosivos concentram-se nas áreas de alto risco à erosão linear por ravinas e de baixo risco por voçorocas, no entanto, a maioria são voçorocas, o que leva a supor que muitas delas podem ter se iniciado como ravinas e evoluído para voçorocas, como mostram muitos dos cadastros efetuados pelo IPT/ CELG (1998). Pode-se perceber, ainda, certa correspondência espacial entre a suscetibilidade à erosão linear $e$ laminar, embora esta seja espacialmente mais restrita (quatro conjuntos).

Em suma, os focos erosivos podem estar relacionados a processos de evolução de altas bacias em processo de dissecação erosiva (este caso) em bordas de planaltos e, ao mesmo tempo, de reativação de cabeceiras de drenagem, porém aceleradas e com claras evidências de ser resposta à ocupação intensiva e inadequada de terras, em flagrante desrespeito à legislação ambiental, que desde meados de 1960 já determinava áreas de proteção em nascentes, margens fluviais e terrenos declivosos.

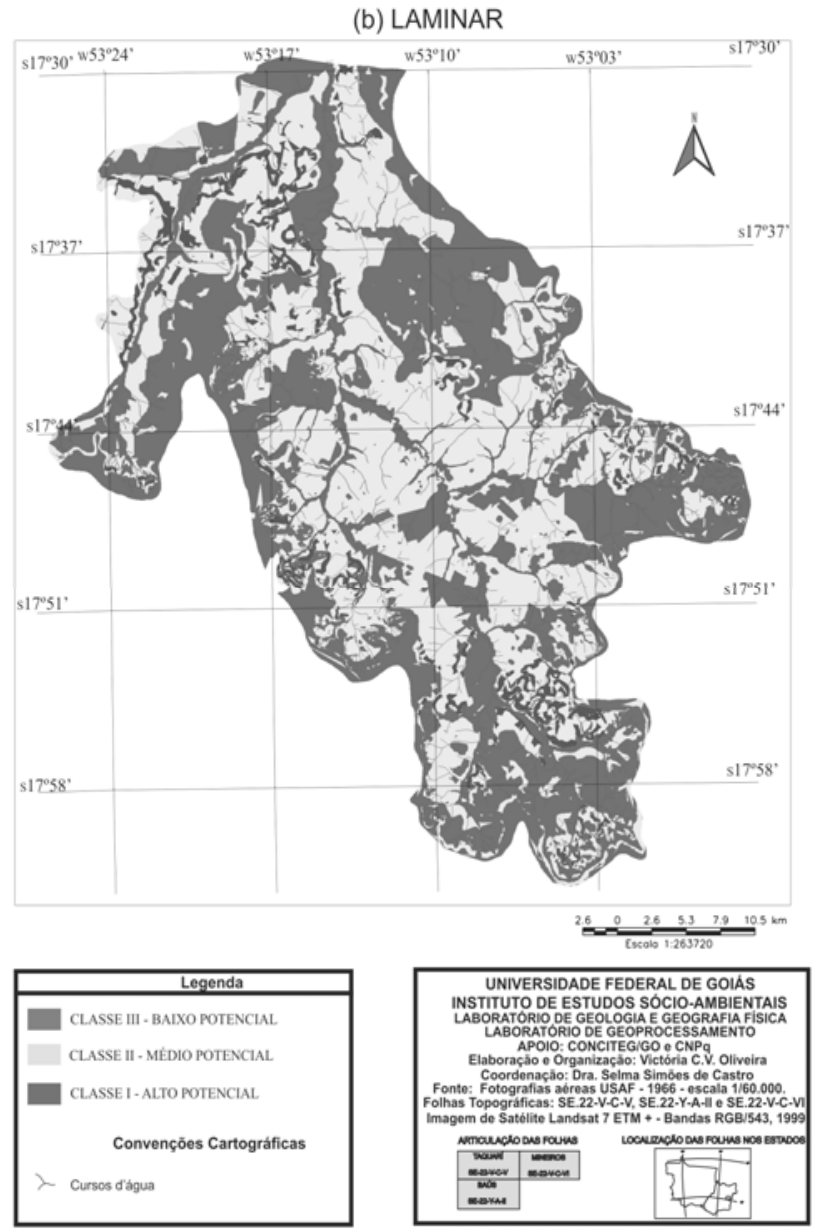

Figura 4 Risco à erosão linear e laminar. A maior parte da área tem suscetibilidade elevada. Fonte: XAVIER e CASTRO(2005), OLIVEIRA e CASTRO (2005). 

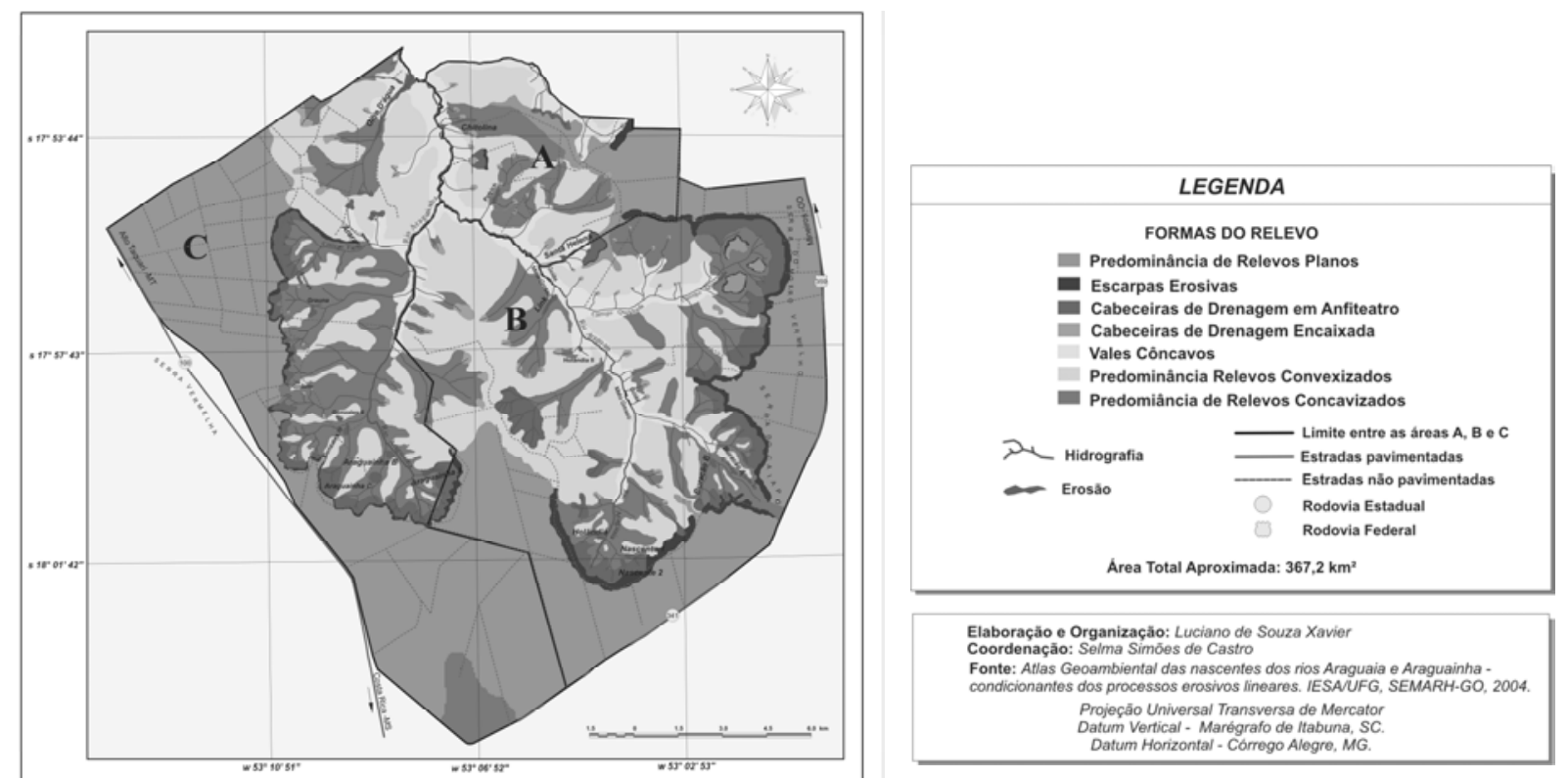

Figura 5 Morfologia do relevo onde se nota a relação entre voçorocas e relevos concavizados. Fonte: CASTRO, XAVIER e BARBALHO (2004).

\section{As nascentes dos rios Araguaia e Araguainha}

Representada na Fig. 1, a área das nascentes abrange cerca de $367 \mathrm{~km}^{2}$ e concentra o expressivo número de 20 voçorocas, sobretudo de grande porte, que reproduzem o padrão de distribuição e de correlação com os atributos do meio físico e de uso já relatados. As duas maiores são a Chitolina do lado Goiano e a Olho D'Água + Olho d'Água I (conectadas) do lado mato-grossense. Deve-se destacar, no entanto, que há explícita relação entre elas e as formas concavizadas que acompanham as nascentes e, sobretudo, os vales, algumas vezes adentrando-os (Fig. 5). Com base no levantamento topográfico detalhado da voçoroca Chitolina e seu entorno (Fig. 6), verifica-se a presença a montante de concavidade alongada e aberta para o topo e, na porção terminal da vertente, declividades mais acentuadas (TERRACARTA, 2001).

Segundo BOULET (2001), a voçoroca Chitolina surgiu em dezembro de 1983, de modo súbito e no verão seguinte atingiu $450 \mathrm{~m}$ de comprimento, $8 \mathrm{~m}$ de profundidade e $10 \mathrm{~m}$ de largura. Segundo este autor, as fotos aéreas das décadas de 1960 e 1970 mostram que a jusante de onde ela se situa hoje, havia uma concavidade alongada (o autor chamou de talvegue) e que a vegetação predominante era de campo limpo, entremeada com áreas de campo sujo e capões de mato. 0 cultivo da soja começou em 1981 e, em 1997, foram construídas duas curvas de contenção de um pouco mais de $1,70 \mathrm{~m}$ de altura, com 4 a $5 \mathrm{~m}$ de base, promovendo certa desaceleração do seu avanço longitudinal, mas não do lateral. As imagens LANDSAT da década de
1980 e 1990 revelaram, conforme o autor, que a erosão só fica visível na escala 1:100000 em 1988. Além de descrever mais de uma direção no seu primeiro ano, quando não tinha mais que 160 $\mathrm{m}$ de comprimento, ela dobrou de tamanho no ano seguinte, em sentido quase perpendicular ao entalhe inicial, quando sofreu nova inflexão E-W, seguida de outra NE-SW, para, em seguida, tornar-se retilínea com direção E-W. Vale lembrar que essas são as direções estruturais dominantes na região. Em 1999 já apresentava mais de $1000 \mathrm{~m}$ de extensão.

A avaliação da aptidão agrícola das terras (Fig. 7) revelou que mais de $50 \%$ da área apresenta boa aptidão para lavouras de ciclo curto e longo, porém no nível de manejo $\mathrm{C}$, isto é, com elevada tecnologia. No caso contrário, nível baixo, apresentam aptidão regular e correspondem à superfícies elevadas. Cerca de $13 \%$ da área apresenta aptidão regular, necessita de manejo elevado, correspondendo à zona rebaixada. Cerca de $22 \%$ apresenta restrição em geral, ou não apresenta aptidão e corresponde aos setores mais declivosos das nascentes e fundos de vale. As voçorocas concentram-se principalmente nas áreas que apresentam aptidão restrita para lavouras e/ou pastagens plantadas mesmo bem manejadas (classe $4 p$ ), secundariamente nas terras sem aptidão (classe 6) e, apenas em dois casos, em áreas com aptidão restrita para lavouras tanto de ciclo curto como longo no nível de manejo $\mathrm{C}$ e $\mathrm{B}$ sendo inaptas para o manejo $\mathrm{A}$, classe 3 (b) c, embora na transição para a classe 6. Portanto, as voçorocas encontram-se em área com restrições a lavoura e pastagem. 

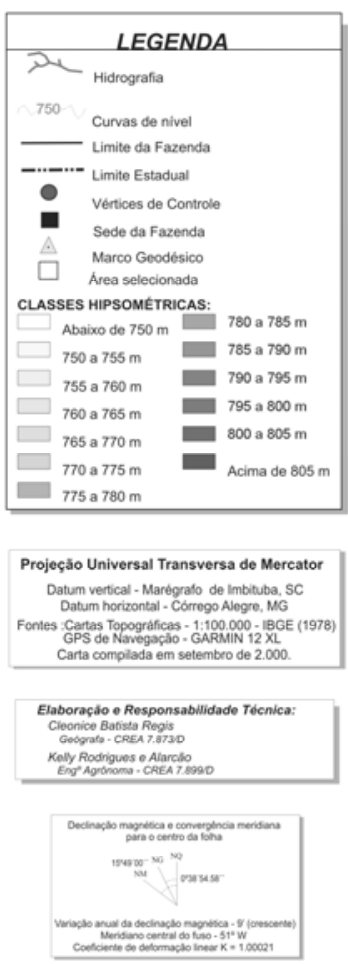

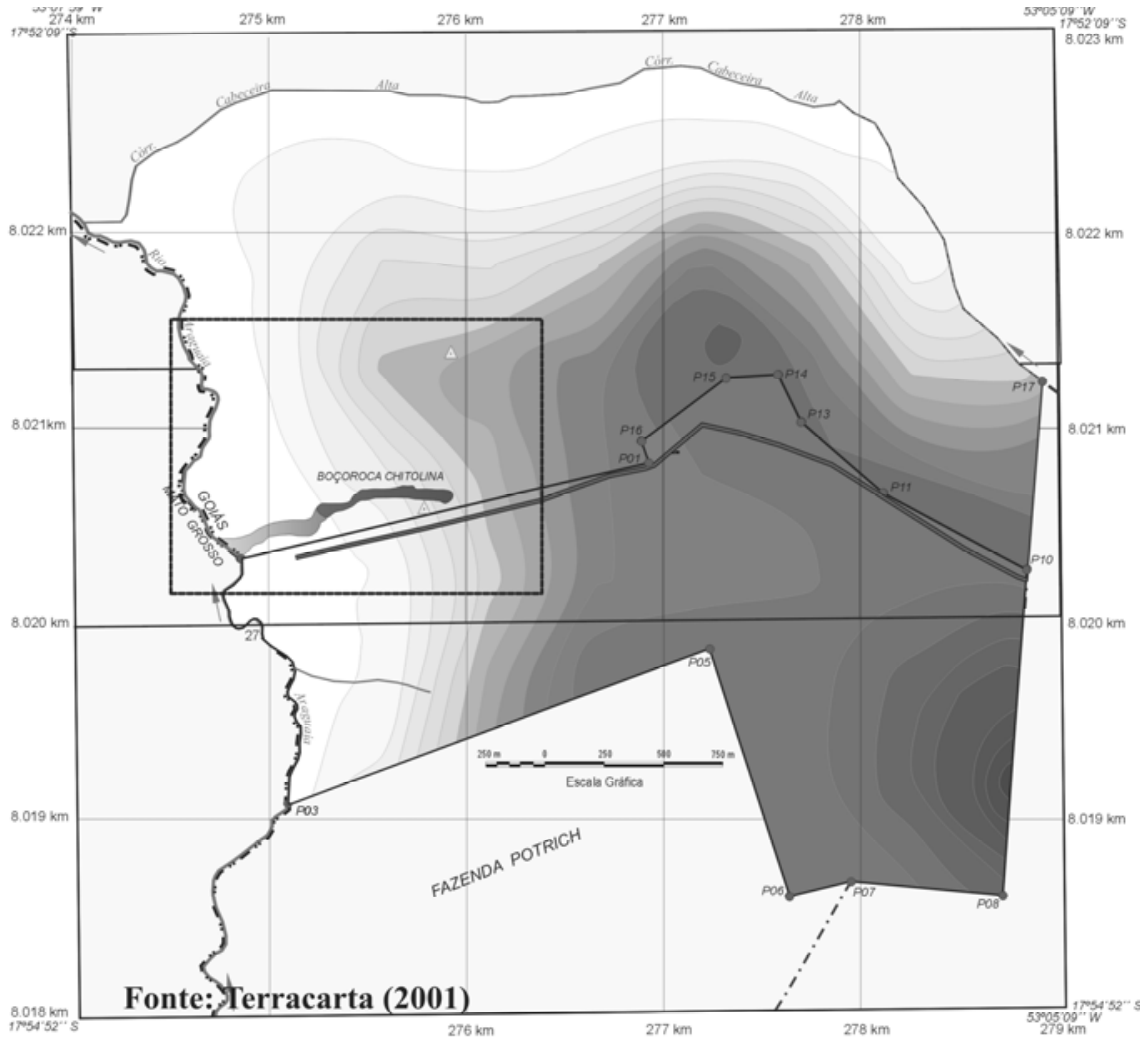

Figura 6 Vertente da Chitolina. Adaptado de TERRACARTA (2001).
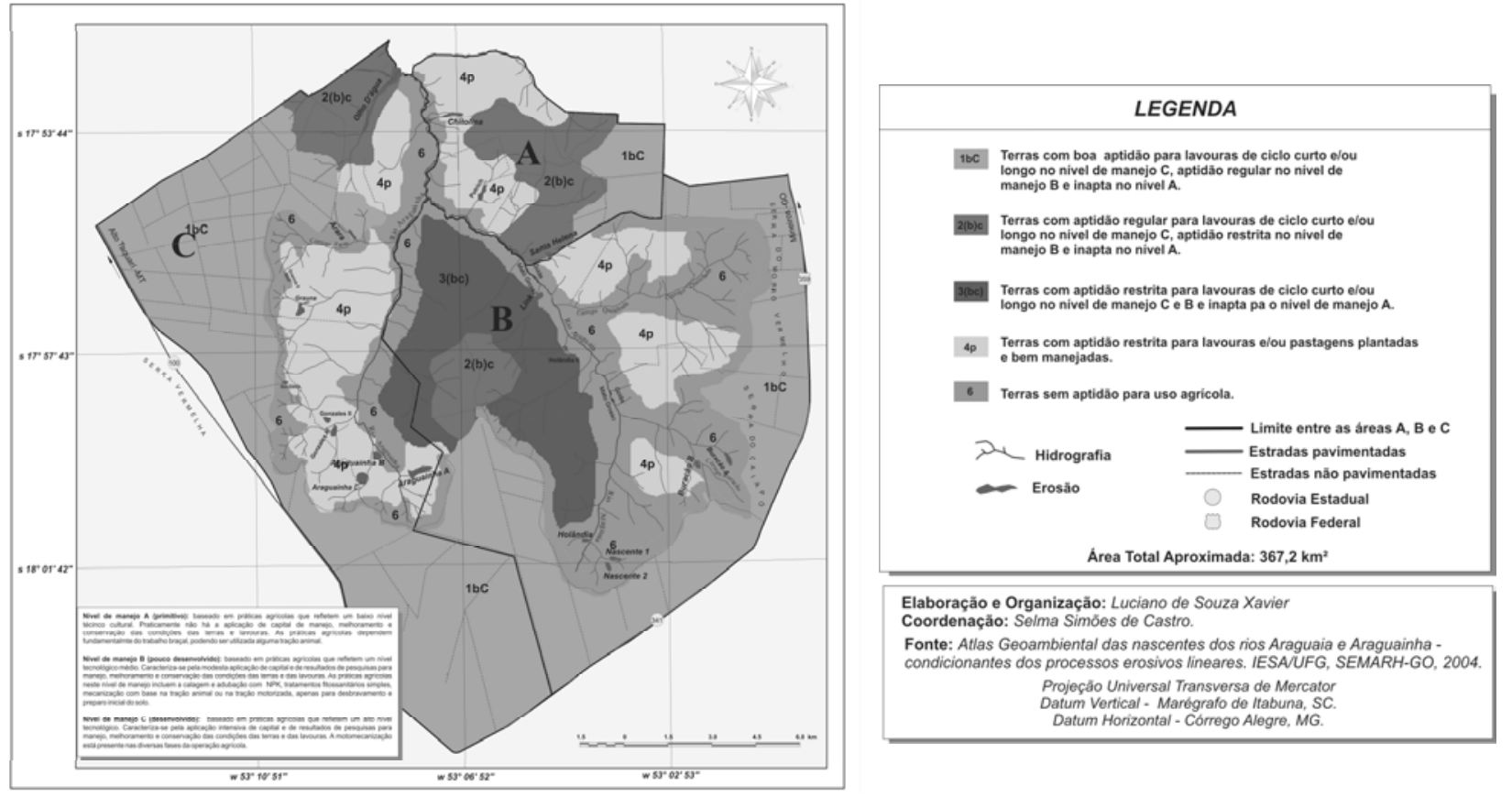

Figura 7 Aptidão agrícola das terras. Adaptado de CASTRO, XAVIER e BARBALHO (2004). 
CASTRO, XAVIER e MACEDO (no prelo), ao analisarem o uso do solo de 1976 e 1999, constataram claramente que a Mata de Galeria ocupa atualmente pouco menos de $5 \%$ da área e 0 Cerrado Arbóreo diminuiu para menos de $15 \%$, cada um representando cerca da metade do que cobriam em 1976. Verificaram também que grande parte da área já estava ocupada por culturas e pastagens, respectivamente $20 \%$ e $57 \%$, significando o triplo e o dobro de área em relação a 1976. A soma de áreas com Cerrado Arbóreo Aberto e Vegetação sujeita a inundação (campos úmidos) já não passa de $1 \%$, sendo quase 0 dobro em 1976, e relacionando-se justamente com as concavidades do relevo. Nesse período, também aumentou considerávelmente o número de focos erosivos na área, de dois para 20 , majoritariamente relacionados com as áreas de pastagem e agricultura que invadiram também as concavidades, com predomínio notável da primeira, em quase o dobro em relação às áreas agrícolas. Segundo os mesmos autores, em 2003 algumas das áreas com pastagem estavam sendo substituídas por agricultura (soja), como no entorno da voçoroca Chitolina, aliás, confirmado em trabalho de campo recente (agosto, 2005). Constataram ainda, quanto ao manejo das terras, que predominam as práticas de espaçamentos estruturais de terraços em nível, onde as curvas são visíveis por todas as áreas de cultura. Porém, em campo, nem sempre estão adequadas a fatores como solo, declividade e formas do relevo para o cálculo dos espaçamentos e que alguns terraços em nível encontram-se em solos arenosos de declividades variadas, sem evidente adequação, principalmente com suas aptidões agrícolas. Nas áreas de pastagem, aquelas com evidências de manejo desse tipo, são nitidamente inferiores às de cultura e, além disso, algumas ocorrem em declividades superiores a $12 \%$, sem qualquer tipo de prática conservacionista, o que é um agravante considerando-se também os solos arenosos já degradados pelos usos anteriores. Os terraços em nivel aparecem em grande parte das terras goianas e menos do lado mato-grossense. As demais áreas que não se referem às práticas de manejo correspondem às áreas de vegetação remanescente, sem uso agropecuário. Constataram, por fim, que as áreas com uso inadequado (bordas de chapada ou em fundos de vale, canais de drenagem e nascentes de córrego) estão significativamente desmatadas, em flagrante descumprimento legal, como já exposto. Ressalte-se que os focos erosivos situamse em áreas sensíveis com uso inadequado (margens de canais, nascentes e anfiteatros de cabeceiras de drenagem), mesmo quando se situam em áreas adjacentes à vegetação natural relativamente preservada, estando presente, muitas vezes, o manejo inadequado na vertente oposta (ver voçoroca Olho d'água).

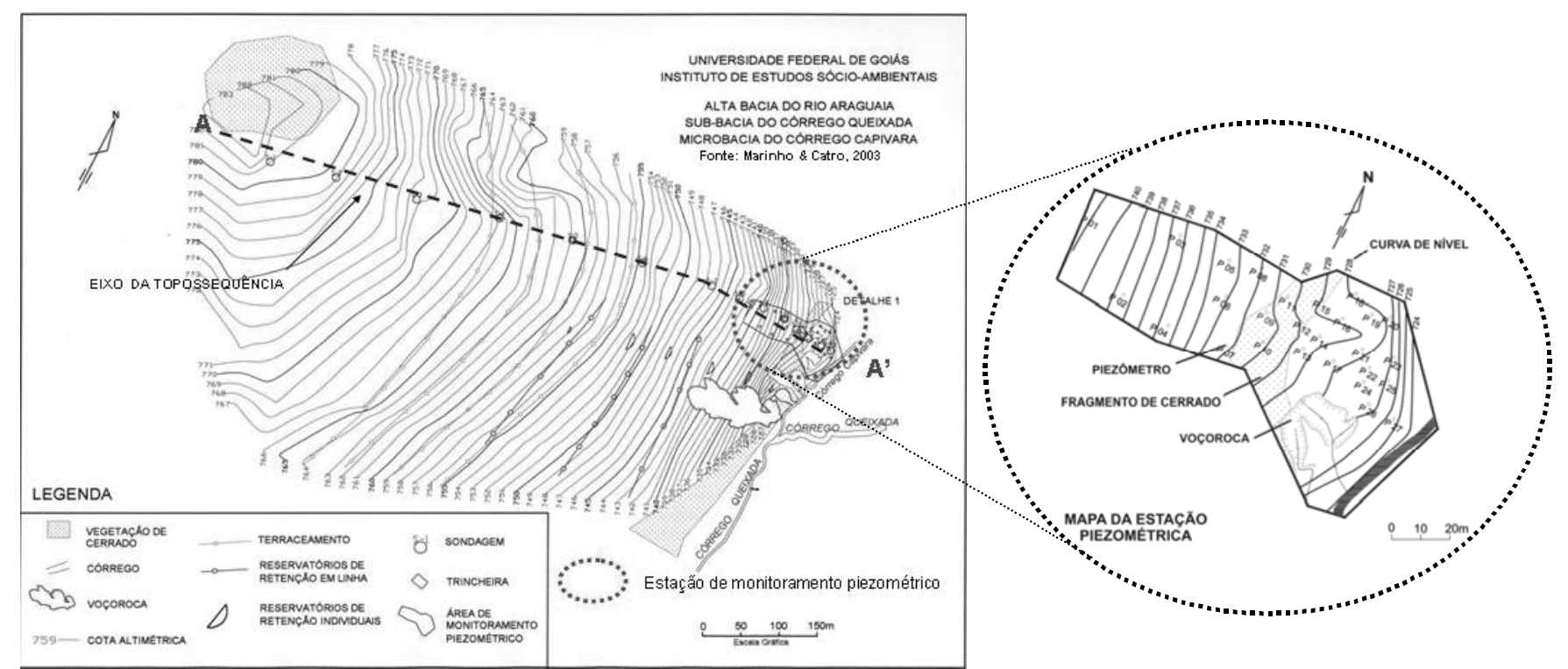

Figura 8 Topografia da vertente indicando o eixo da toposseqüência, a estação piezométrica e os focos erosivos. Fonte: MARINHO e CASTRO (2003).

O levantamento de solos no entorno da voçoroca Chitolina foi feito em 3 toposseqüências, uma próxima à Chapada, perpendicular à voçoroca, outra transversal à concavidade a montante da voçoroca e, outra, paralela ao seu eixo jusante, inclusive com sondagens profundas. BOULET (2001) confirmou que esta última coincide grosso modo com o eixo da citada concavidade a 
montante (denominada de berço pelo autor), próxima à Chapada, e também a jusante com a pré-existente (denominada de talvegue pelo autor), embora descreva inflexões. $\mathrm{Na}$ área de contribuição da voçoroca predomina o Latossolo Vermelho Amarelo distrófico no topo (adentrando a Chapada) e em direção à jusante sucedem-se Neossolos Quartzarênicos órticos distróficos, dominantes na maior parte da vertente e junto ao rio Araguaia, o
Gleissolo Melânico distrófico, em parte sob pacote arenoso fino e esbranquiçado com cerca de $2 \mathrm{~m}$ de espessura, todos com restrição de fertilidade e suscetibilidade erosiva. 0 proprietário relatou que desde 1997, a velocidade de expansão remontante diminuiu quando ele construiu curvas de nível a montante dela, embora tenha iniciado ramos laterais, os quais estão diretamente relacionados a estas curvas (BOULET, 2001).

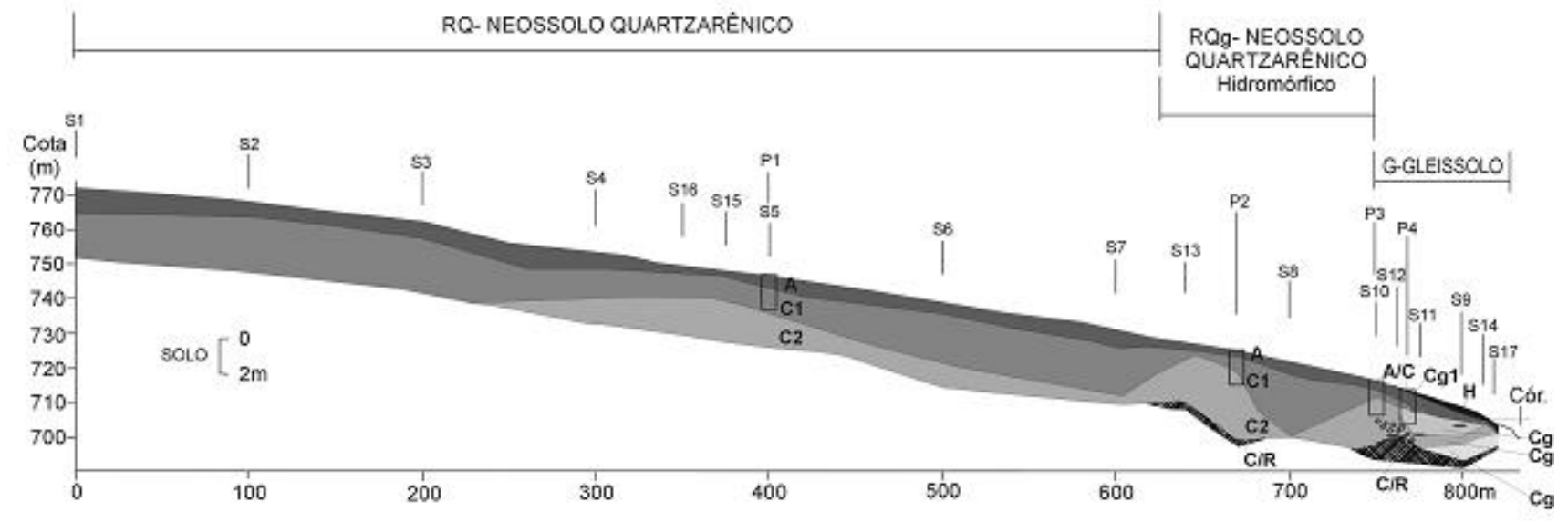

\section{CONVENÇÕES CARTOGRÁFICAS}
S1 - Sondagem
- P1 - Perfil de solo (trincheira)
$\triangle 0$ - NA -Nivel d'água
80 Nódulos concrecionários

\section{LEGENDA}

\section{(RQ) NEOSSOLO QUARTZARËNICO}

A Horizonte A- Bruno amarelado (10YR 4/4 e 5/4), arenoso fino, blocos subangulares médios a grandes, fortes, porosidade intergrsos, friável, nāo plástico e naెo pegajoso aprofundando-se até $\mathrm{S} 6$ (30-300om), transiçà gradual plana

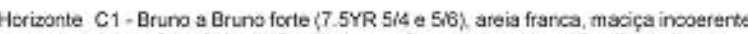

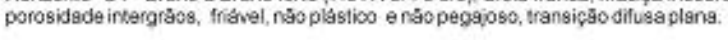

Herizonte C2 - Bruno forte (7.5YR 518 e 5r8) e Vermelho amsrela (5YR 5r8) em $\$ 18$ e \$15), areia franca, meciça hccerente, porcsidade intergrâs, fríwel nao plastico o nä pagajosa.

\section{(RQg) NEOSSOLO QUARTZARÊNICO Hidromórfico}

A

Horizante A - Bruno amereledo (10YR 5/4) a Bruno (10YR 5/3) para jusante, arencso fino, blocos pequenos e muino pequenos fracos em $0.3 \mathrm{~cm}$ e macica inccerente abeixo Possui porosidada intergedas, friável, náo plástico e nda pegajosa, transiça gradual plans.

Horizonte C1 - Brund forte (7.5YR 5.9 e 5/8) arengso macica incoerente. Possai

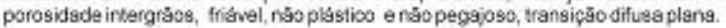

Herizonte C2 - Vermeho amarelo (5YR S16 e 5V8), maciça inccerente, com um pouco de argla e slaumas manchas de areia lavgda. Porosidade intergräos, friável, nב̃o plłstico e

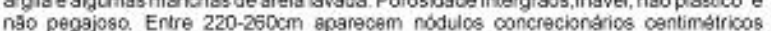
avamel hados trarsiçäo gradual irreguler

CIR Herizonte CIR - Vermehs (2YR 5ib) arenosa, masça incoerente, porosidade

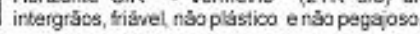

\section{(G) GLEISSOLO}

H. Horizonte A histion turtoso - prato (2.3Y) . com mataria organica a raizes fasciculadas finas, arencas ind, blocos arrodontadbs pequenos a muto pequenos frocos, arglo-arenoso e argilo-sitoso a jusarne, plástico e pegaicso. transiçäo clara plana.

Horizonte ANC - Bruno amarolado escuro (10YR 4/4) aranoso fino, blocos pequenos e muto pequence fracos em superfice e macica abaixa. Possi

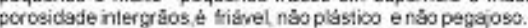

Cg1 Horizomte Ca1 - Bruno forte (7.5YR S/8) greig franes, macica Possui porosidade intergasos, fritusi, nato plastico a nato pagajos, transicha gradual plang.

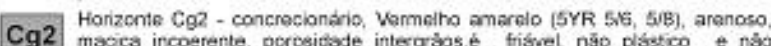

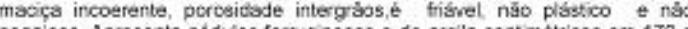
cepajoso. Apresents nodulas ferugnosos a de grgila cancmetricos em 170 .

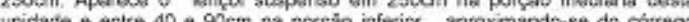
Capivarg, vensiçogradual plang.

Horizonte C Glacado Seprolto grosso 1 - Bruno svermehado claro \{2 5YR 7/4\}e varmeho claro areia grossacom manches rosees o avermehadas e noducos

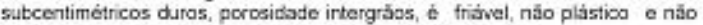
pegajoso. Ocorre lençol suspenso, transiçaso dfusa ifregula:

Cg4 Horizonte C Glaizado Saprólto grosso 2 - Amarelo (10YR 78, 7iB), aren grassa com nodalas roseas a avermehadas, maeça incoarente, porosidate intergräos \& fridvel năo plastico enåo pegajoso, transiça dínsa iregular. Horizonte C/R - Vermeno (2.5YR 5/B, 4/8 abaixo), arenc60, macisa incoereme,

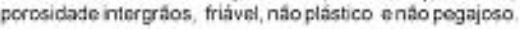

Figura 9 Toposseqüência estudada. Fonte: MARINHO e CASTRO (2003). 
Dois fatos importantes foram descobertos por BOULET (1981). Primeiro, a ocorrência de níveis argilosos em profundidades maiores que 1 metro, dos trajetos médios para jusante, o que, segundo ele, corresponde a camadas de alteração, que podem saturar rapidamente e provocar 0 aparecimento de fluxos laterais sub-superficiais sobrejacentes direcionados para o eixo da concavidade e desta para a voçoroca. Segundo, a presença de turfa na base junto à várzea, sobre camada arenosa de forma lenticular, sobreposta a outra de areia branca, caracterizando um Gleissolo, às quais ele atribuiu origem aluvial e condições de saturação prolongada. Sobre a turfa constatou a presença de areia esbranquiçada configurando feição similar a leque (visível nas imagens de satélite e tomadas aéreas), o que levaria a supor um soterra-mento recente do solo préexistente, embora 0 autor tenha aventado também a possibilidade de novo depósito aluvial recente no segmento da toposseqüência.

Os ensaios infiltração em campo, de condutividade hidráulica saturada apresentados e discutidos pelo referido autor mostram menores condutividades na profundidade de 0 a $20 \mathrm{~cm}$, da ordem de 30 a $50 \mathrm{~mm} \cdot \mathrm{h}^{-1}$ e bem maiores entre 60 e $80 \mathrm{~cm}$, da ordem de $200 \mathrm{~mm} \cdot \mathrm{h}^{-1}$, significando possibilidade de incremento do escoamento superficial durante episódios de chuvas intensas que facilmente podem chegar a $100 \mathrm{~mm} \cdot \mathrm{h}^{-1}$, conforme dados citados por outros autores (ASSAD, ASSAD e EVANGELISTA, 1994) e corroborados pelos estudos específicos de RAMOS e CASTRO (2003). Estes, além de confirmarem a sazonalidade conhecida para o domínio do Cerrado (Aw - tropical sub-úmido de Köppen) com chuvas intensas de verão, chamam a atenção para o fato de que estas são de curta duração, mas podendo ocorrer vários episódios num mesmo dia, principalmente à noite. Isto permite supor que solos arenosos, apesar de drenarem relativamente bem, quando mais rasos, como nos segmentos inferiores das vertentes, além da infiltração, recebem intensos fluxos laterais tanto superficiais como subsuperficiais, podendo saturar rapidamente e potencializar ainda mais o poder erosivo dos fluxos, dado o lençol freático raso, com risco de exfiltração. Sob condições de uso e manejo inadequados, fatores como trilhas de gado, cercas e valas de divisa transversais às curvas de nível e mesmo os terraços mal dimensionados podem facilmente induzir à concentração do escoamento superficial, podendo causar ravinas que eventualmente interceptam o lençol. Trata-se, portanto, de uma dinâmica complexa por ser multifatorial.

Em síntese, 0 indicador mais significativo para a compreensão do processo de voçorocamento é: o alojamento em zona de concavidade de origem geológico-geomorfológica, que exerce controle na instalação e aceleração do processo quando 0 lençol é interceptado e descomprimido, o que pode ser induzido pelo uso e manejo inadequados como revelaram os exemplos descritos pela CEG (1998) e IPT (1998) para a região.

\section{Estudos do comportamento hidrológico da vertente do Córrego Capivara}

Na microbacia do Córrego Queixada, onde se desenvolveram estudos pedohidrológicos detalhados (Fig. 1), encontra-se a vertente do córrego Capivara um pequeno afluente da margem direita do córrego Queixada. Nesta vertente, representativa de indicador para voçorocamento, localiza-se também a toposseqüência e a estação piezométrica e é o local onde foram realizados os caminhamentos geoelétricos para monitoramento do lençol freático e detecção do topo rochoso (Fig. 8).

A vertente é suavemente convexa, com declives inferiores a $8 \%$, com pouco menos de $800 \mathrm{~m}$ de extensão. 0 sistema pedológico revelou a sucessão lateral de solos arenosos finos, ácidos, muito espessos a montante e sucessivamente menos espessos a jusante: Neossolo Quartzarênico álico (RQa) - Neossolo Quartzarênico Hidromórfico distrófico (RQd) e Gleissolo Melânico (GMd) e, localmente, Hístico, ambos distróficos (EMBRAPA, 1999) (Fig. 9).

Na Fig. 9 pode-se constatar: (a) paralelismo entre os horizontes que, com a topografia atual, permite concluir que são produtos da pedogênese e morfogênese recentes (Quaternária) e congruente com a esculturação do interflúvio; (b) que os $R Q$ não são pedogeneticamente desenvolvidos e são produtos da alteração do arenito Botucatu subjacente, por sua textura e mineralogia, tratando-se, portanto, de evolução in situ; (c) que o $\mathrm{RQg}$ apresenta horizonte plíntico típico de zona de oscilação do nivel freático; (d) que o GM de jusante desenvolve-se em sedimentos provavelmente aluviais e relacionados ao antigo nível da planície fluvial restrita, permanentemente saturada; (e) que estes sedimentos depositaram-se em concavidade pré-existente, que nada tem a ver com voçoroca pois que não há nenhum no eixo da toposseqüência.

$\mathrm{Na}$ Tab. 3 pode-se constatar a relativa homogeneidade dos solos, sua textura arenosa dominante, sua acidez, os baixos valores de saturação em bases e, elevados, em alumínio, os baixos teores $C$, exceto no horizonte superficial do Gleissolo, todos corroborando o exposto na literatura a respeito desses tipos de solos, em particular, sua baixa coesão e a suscetibilidade erosiva decorrente, além do risco à erosão se forem mal manejados (EMBRAPA, 1999). 
Tabela 3 Resultados analíticos dos solos da Toposseqüência. Fonte: MARINHO e CASTRO (2003).

\begin{tabular}{|c|c|c|c|c|c|c|c|c|c|c|c|c|c|c|c|c|c|c|c|}
\hline $\begin{array}{l}\text { Profun- } \\
\text { didade }\end{array}$ & $\begin{array}{l}\text { Hori- } \\
\text { zonte }\end{array}$ & $\begin{array}{l}\text { Areia } \\
\text { grossa }\end{array}$ & $\begin{array}{l}\text { Areia } \\
\text { fina }\end{array}$ & Silte & $\begin{array}{c}\text { Argila } \\
(\mathrm{NaOH})\end{array}$ & $\begin{array}{l}\text { Argila } \\
\left(\mathrm{H}_{2} \mathrm{O}\right)\end{array}$ & $\begin{array}{l}\text { Grau } \\
\text { Floc. }\end{array}$ & C & $\begin{array}{l}\text { Mat. } \\
\text { Orgân. }\end{array}$ & $\begin{array}{c}\mathrm{PH} \\
\left(\mathrm{H}_{2} \mathrm{O}\right)\end{array}$ & $\begin{array}{c}\mathrm{PH} \\
(\mathrm{KCL})\end{array}$ & $\begin{array}{l}\text { Soma } \\
\text { Bases }\end{array}$ & $\mathrm{Al}$ & $\mathrm{H}$ & СTC & $\begin{array}{l}\text { Sat. } \\
\text { Bases }\end{array}$ & $\begin{array}{c}\text { Sat. } \\
\text { Al }\end{array}$ & $P$ & $\begin{array}{l}\text { Ativ. } \\
\text { Arg. }\end{array}$ \\
\hline & & $\%$ & $\%$ & $\%$ & $\%$ & $\%$ & $\%$ & $\%$ & $\%$ & & & $\begin{array}{c}\mathrm{mE} / 100 \\
\mathrm{ml}\end{array}$ & $\begin{array}{c}\mathrm{mE} / 100 \\
\mathrm{ml}\end{array}$ & $\begin{array}{c}\mathrm{mE} / 100 \\
\mathrm{ml}\end{array}$ & $\begin{array}{c}\mathrm{mE} / 100 \\
\mathrm{ml}\end{array}$ & $\%$ & $\%$ & ppm & $\begin{array}{c}\mathrm{mE} / 100 \\
\mathrm{ml}\end{array}$ \\
\hline \multicolumn{20}{|c|}{ Trincheira 01 - neossolo quartzarênico } \\
\hline $8 \mathrm{~cm}$ & $A$ & 18 & 76 & 1 & 5 & 3 & 40 & 0,58 & 1 & 4,9 & 3,8 & 0,3 & 0,5 & 3,1 & 3,9 & 8 & 62 & 0,5 & 26 \\
\hline $25 \mathrm{~cm}$ & $\mathrm{~A} / \mathrm{C}$ & 19 & 77 & 1 & 3 & 2 & 33 & 0,35 & 0,6 & 4,9 & 3,9 & 0,3 & 0,5 & 1,5 & 2,3 & 13 & 62 & 3,7 & 24 \\
\hline $50 \mathrm{~cm}$ & $\mathrm{C} / \mathrm{A}$ & 17 & 79 & 1 & 3 & 2 & 33 & 0,17 & 0,3 & 4,9 & 4 & 0,3 & 0,4 & 1 & 1,7 & 18 & 57 & 2,1 & 31 \\
\hline $75 \mathrm{~cm}$ & A1 & 18 & 79 & 1 & 2 & 1 & 50 & 0,17 & 0,3 & 4,6 & 3,9 & 0,3 & 0,4 & 0,8 & 1,5 & 20 & 57 & 1,2 & 37 \\
\hline $100 \mathrm{~cm}$ & C1 & 13 & 83 & 1 & 3 & 2 & 33 & 0,12 & 0,2 & 4,5 & 4 & 0,3 & 0,4 & 1,8 & 2,5 & 12 & 57 & 2,8 & 65 \\
\hline $140 \mathrm{~cm}$ & C1 & 16 & 77 & 3 & 4 & 2 & 50 & 0,12 & 0,2 & 4,5 & 3,9 & 0,3 & 0,3 & 1,5 & 2,1 & 14 & 50 & 0,8 & 39 \\
\hline $450 \mathrm{~cm}$ & $\mathrm{C} 2$ & 11 & 82 & 3 & 4 & 0 & 100 & 0,12 & 0,2 & 4,6 & 4,2 & 0,3 & 0,3 & 0,9 & 1,5 & 20 & 50 & 0,5 & 24 \\
\hline \multicolumn{20}{|c|}{ Trincheira 03 - neossolo quartzarênico hidromórfico } \\
\hline $05 \mathrm{~cm}$ & $\mathrm{~A}$ & 11 & 85 & 1 & 3 & 2 & 33 & 0,23 & 0,4 & 4,8 & 3,7 & 0,3 & 0,4 & 3,8 & 4,5 & 7 & 57 & 4,7 & 116 \\
\hline $30-40 \mathrm{~cm}$ & $\mathrm{~A} / \mathrm{C}$ & 15 & 81 & 2 & 2 & 1 & 50 & 0,17 & 0,3 & 5 & 4 & 0,3 & 0,3 & 2,7 & 3,3 & 9 & 50 & 2,4 & 127 \\
\hline $60 \mathrm{~cm}$ & $\mathrm{C} / \mathrm{A}$ & 10 & 86 & 2 & 2 & 1 & 50 & 0,17 & 0,3 & 5 & 3,9 & 0,3 & 0,3 & 2,3 & 2,9 & 10 & 50 & 2,4 & 107 \\
\hline $74 \mathrm{~cm}$ & $\mathrm{C} 1$ & 13 & 77 & 1 & 9 & 8 & 11 & 0,17 & 0,3 & 5,1 & 3,9 & 0,3 & 0,3 & 2,5 & 3,1 & 10 & 50 & 4 & 26 \\
\hline $90 \mathrm{~cm}$ & $\mathrm{C} 2$ & 9 & 81 & 1 & 9 & 8 & 11 & 0,12 & 0,2 & 4,8 & 3,9 & 0,3 & 0,3 & 1,9 & 2,5 & 12 & 50 & 1,8 & 22 \\
\hline $150 \mathrm{~cm}$ & $\mathrm{C} 2$ & 10 & 79 & 1 & 10 & 0 & 100 & 0,12 & 0,2 & 4,7 & 4,1 & 0,3 & 0,3 & 1,5 & 2,1 & 14 & 50 & 15 & 16 \\
\hline $170 \mathrm{~cm}$ & $\mathrm{C} 2$ & 9 & 82 & 2 & 7 & 6 & 14 & 0,12 & 0,2 & 3,9 & 3,8 & 0,3 & 0,3 & 1,7 & 2,3 & 13 & 50 & 15,5 & 25 \\
\hline $200 \mathrm{~cm}$ & $\mathrm{C} 3$ & 14 & 75 & 2 & 9 & 8 & 11 & 0,12 & 0,2 & 4,8 & 4,1 & 0,3 & 0,3 & 1,7 & 2,3 & 13 & 50 & 16 & 20 \\
\hline \multicolumn{20}{|c|}{ Trincheira 04 - gleissolo } \\
\hline $05 \mathrm{~cm}$ & $A$ & 9 & 87 & 1 & 3 & 2 & 33 & 0,46 & 0,8 & 5,2 & 3,7 & 0,3 & 0,6 & 5,2 & 6,1 & 5 & 67 & 18,8 & 134 \\
\hline $23 \mathrm{~cm}$ & $\mathrm{~A} / \mathrm{C}$ & 15 & 82 & 1 & 2 & 1 & 50 & 0,41 & 0,7 & 4,9 & 3,8 & 0,3 & 0,4 & 4 & 4,7 & 6 & 57 & 17 & 143 \\
\hline $55 \mathrm{~cm}$ & $\mathrm{C} / \mathrm{A}$ & 9 & 88 & 1 & 2 & 1 & 50 & 0,17 & 0,3 & 5 & 3,8 & 0,3 & 0,4 & 2,2 & 2,9 & 10 & 57 & 16,5 & 107 \\
\hline $105 \mathrm{~cm}$ & $\mathrm{C} 1$ & 13 & 79 & 1 & 7 & 0 & 100 & 0,17 & 0,3 & 4,4 & 4 & 0,3 & 0,2 & 1,8 & 2,3 & 13 & 40 & 15 & 22 \\
\hline $180 \mathrm{~cm}$ & $\mathrm{Cg}$ & 10 & 80 & 1 & 9 & 0 & 100 & 0,12 & 0,2 & 5,1 & 4,4 & 0,3 & 0,2 & 1,2 & 1,7 & 18 & 40 & 15 & 13 \\
\hline
\end{tabular}

As características micromorfológicas nas amostras dos horizontes dos solos confirmam as observações de campo e permitem constatar nos $R Q$ uma porosidade intergrãos moderada a fortemente interconectada, mais fina nos horizontes superficiais e maior nos demais. No horizonte subsuperficial do GM, devido ao maior teor de argila, a porosidade é também muito fina. As microestruturas são granulares típicas de grãos simples (BULLOCK et al., 1985) no RQ, localmente como microagregadas (enáulicas) incipientes com feições nodulares ferruginosas no horizonte plíntico $(\mathrm{RQg})$ e cimentadas (porfíricas) ou em pontes (gefúricas) mal desenvolvidas no horizonte glei (GM). Tais características conferem boa permeabilidade ao $R Q$ e $R Q g$, embora reduzidas em seus horizontes superficiais. No GM, os horizontes, embora porosos, estão saturados. Em função disso, supõe-se boa infiltração e percolação nos $R Q$, saturação sazonal no horizonte subsuperficial do RQg e saturação permanente dos horizontes $\mathrm{Cg}$ do GM. Em função dessa hipótese, a instalação dos piezômetros foi feita na porção a jusante da vertente, cobrindo a parte terminal do $R Q$ e toda área representativa do RQg (Fig. 11), conforme instruções de SALOMÃO (1999).

A Fig. 10 mostra os histogramas pluviométrico e piezométrico do período monitorado (2001 a 2003), em que, para fins de ilustração, os níveis freáticos foram agrupados em três conjuntos de poços, conforme a posição topográfica e comportamento.

A correlação entre os dados de chuva e o comportamento do topo freático mostra que no terço inferior da vertente o nível freático respondeu de maneira mais rápida às primeiras chuvas $\mathrm{e}$ mais lentamente depois, o que indica ser o período inicial o que eleva rapidamente o nível freático, facilitado pela pouca espessura dos solos, sua textura arenosa e sua elevada macroporosidade intergrãos, fortemente comunicante (MARINHO e CASTRO, 
2003). Ainda com base nessa figura, o nível freático pode oscilar até $3,0 \mathrm{~m}$ durante $\mathrm{o}$ ano hidrológico, com casos de rebaixamento de $1,5 \mathrm{~m}$ em apenas 10 dias, o que indica drenagem relativamen- te rápida da água infiltrada. Entretanto, essa circulação apresenta altos potenciais hidráulicos em determinados pontos, sobretudo no contato entre solo e rocha alterada, onde pode ocorrer piping.

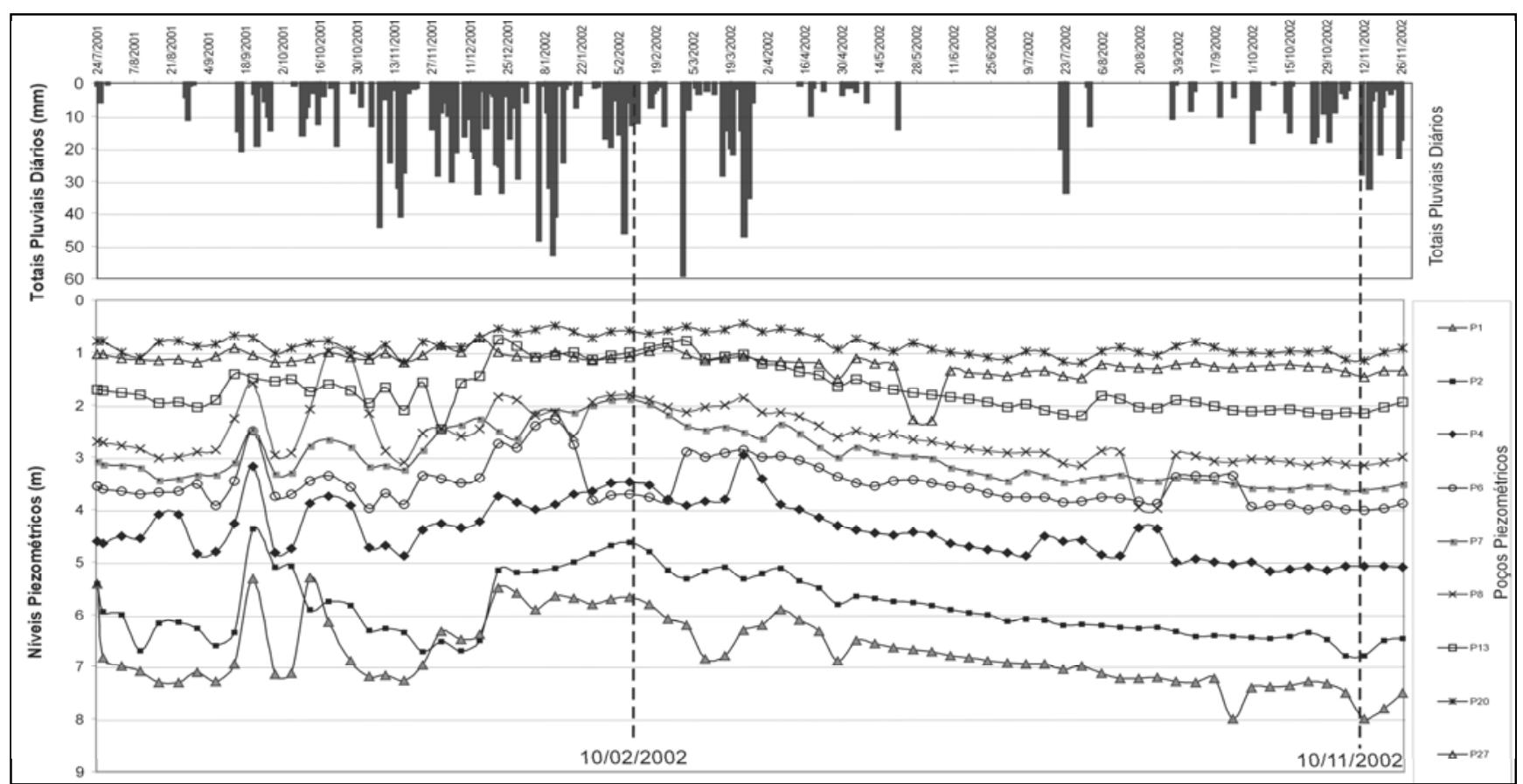

Figura 10 Pluviometria (A) e Piezometria (B) de poços representativos de montante (P1, P2), intermediários (P4, P6, P7 e P8) e de jusante (P13, $20 \mathrm{e}$ P27). Adaptado de MARINHO e CASTRO (2003).
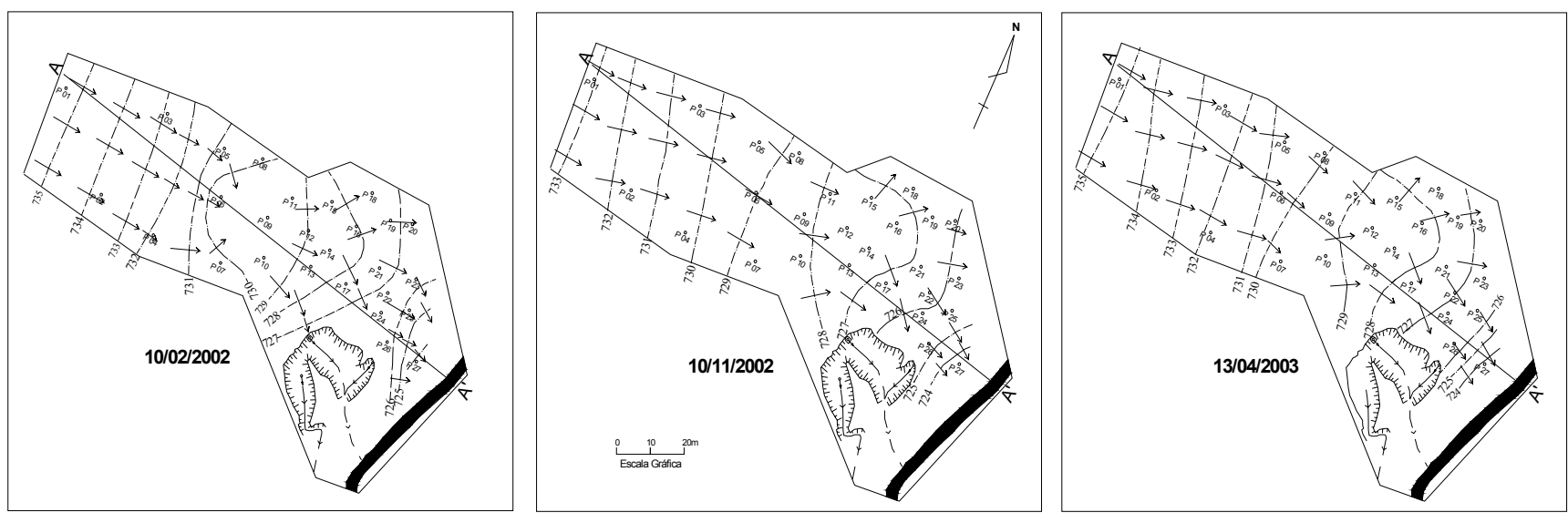

\section{LEGENDA}

ÁREA DE MONITORAMENTO

P 01 PIEZÔMETRO

\section{$724 \ldots$ EQUIPOTENCIAL COM}

DIREÇÃO DO FLUXO HÍDRICO

ALCOVA DE REGRESSÃO
SURGÊNCIA D'ÁGUA

CURSO INTERMITENTE

TALUDE DE EROSÃO

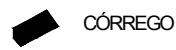

AEÇÃO A-A' DO PERFIL DO
A AENÇOL FREÁTICO

Figura 11 Mapas piezométricos de três momentos significativos: no início, no fim e logo após o térmico na estação chuvosa. Note-se que os pontos de convergência de fluxos subsuperficiais remontam a vertente entre o início e o fim da estação chuvosa e também há convergência dos mesmos para uma pequena voçoroca à esquerda. Fonte: MARINHO e CASTRO (2003). 
Na Fig. 11 são mostrados os mapas piezométricos de dias considerados representativos da dinâmica das curvas de equipotencial. Observa-se um distanciamento entre os equipotenciais nos períodos de baixa do lençol freático na estação seca (b), ao contrário do que ocorre no período de alta na estação chuvosa (a e b) que os aproxima e indica maiores gradientes hidráulicos e, por isso, maior risco à instalação de processos erosivos relacionados com fluxos subsuperficiais concentrados na estação chuvosa. De fato, nessa estação, com altos potenciais hidráulicos, verifica-se a concentração de fluxos próximos à área do poço 06 , na cabeceira da pequena incisão erosiva, próxima ao sopé da encosta e do córrego.

A Fig. 12 ilustra os perfis longitudinais do lençol freático em três momentos apresentados na Fig. 11, de baixo e de alto potencial hidráulico, cujas superfícies piezométricas e gradientes hidráulicos podem ser analisados em conjunto (notar que as escalas vertical e horizontal do perfil são diferentes). Com baixo potencial hidráulico, durante a estação seca, a superfície piezométrica é planar a suavemente convexa. 0 gradiente hidráulico foi da ordem de $0,070 \mathrm{~m} / \mathrm{m}$ de 0 a $113 \mathrm{~m}$ do eixo A-A 'e $0,15 \mathrm{~m} / \mathrm{m}$ de 113 a $123 \mathrm{~m}$, ou seja, alto. Com alto potencial hidráulico, durante a estação chuvosa, a superfície piezométrica é côncava entre 0 e $62 \mathrm{~m}$ do eixo $A-A^{\prime}$, concentrando fluxos no setor do P06, com gradiente de $0,075 \mathrm{~m} / \mathrm{m}$ e, convexa entre 67 e $122 \mathrm{~m}$ do mesmo eixo, divergindo fluxos com alto gradiente hidráulico, da ordem de $0,15 \mathrm{~m} / \mathrm{m}$. Entre 82 e $110 \mathrm{~m}$ do referido eixo, o lençol freático aproxima-se muito da superfície do terreno. Este setor da vertente até o córrego, portanto, é de alto risco ao voçorocamento. Se houver interceptação por sulco ou ravinamento pouco profundo (considerando a cobertura por gramíneas), pode desencadear voçorocamento, descompressão do lençol e evolução remontante relacionada a surgências d'água e formação de piping com grande e rápida descarga do pacote arenoso.

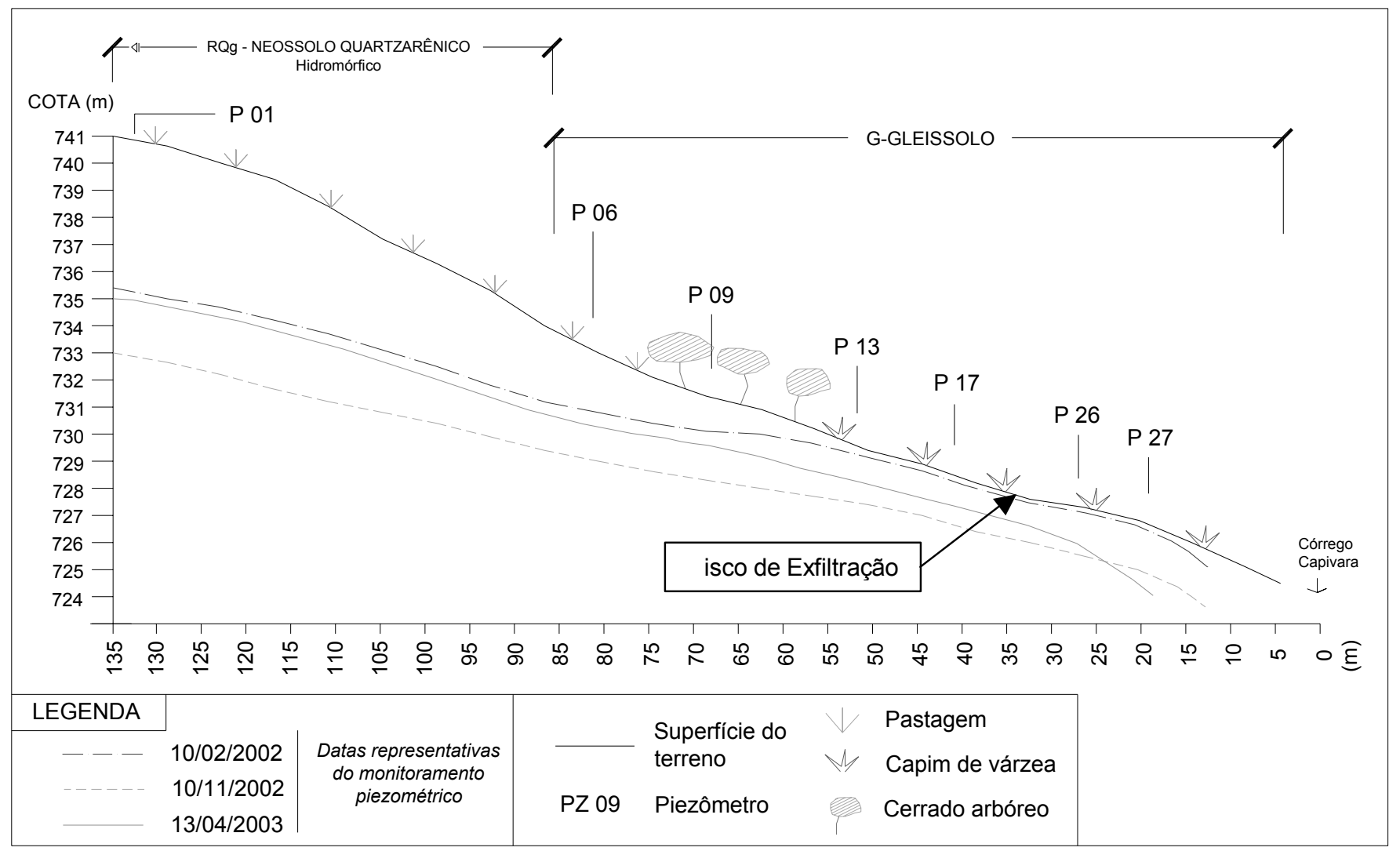

Figura 12 Perfis longitudinais do lençol freático em três dias representativos. Fonte: MARINHO e CASTRO (2003).

A Fig. 13 (GPR) e a Fig. 14 (SEV) mostram dois perfis geoelétricos obtidos para a estação seca e chuvosa. A seção de GPR inicia-se a $80 \mathrm{~m}$ acima do fundo do vale e segue até $840 \mathrm{~m}$ no topo da vertente. Os primeiros refletores registrados, paralelos à topografia (letra $\mathrm{A}$ ), correspondem às ondas aérea e direta do primeiro horizonte do solo. Um segundo horizonte que acompa- 
nha toda vertente aparece a 2,35 $\mathrm{m}$ de profundidade no início do perfil e chega a $26 \mathrm{~m}$ de profundidade no topo da vertente, correspondendo ao topo do lençol freático. Nos primeiros $100 \mathrm{~m}$ da seção, observam-se estruturas nas camadas inferiores exibindo estratificações cruzadas típicas da Formação Botucatu. Ao final deste trecho inicial há uma clara interrupção no sinal a aproximadamente $11 \mathrm{~m}$ de profundidade, sugerindo a existência de uma falha normal. A linha tracejada que indica o topo do freático possui um nível superior correspondente a uma pequena faixa de laterização e a linha contínua mais realçada corresponde ao topo rochoso. Na posição entre 700 a $770 \mathrm{~m}$ ocorre um enfraquecimento do sinal que é interpretado como uma interrupção na camada de laterita por alguma descontinuidade ou falhamento.

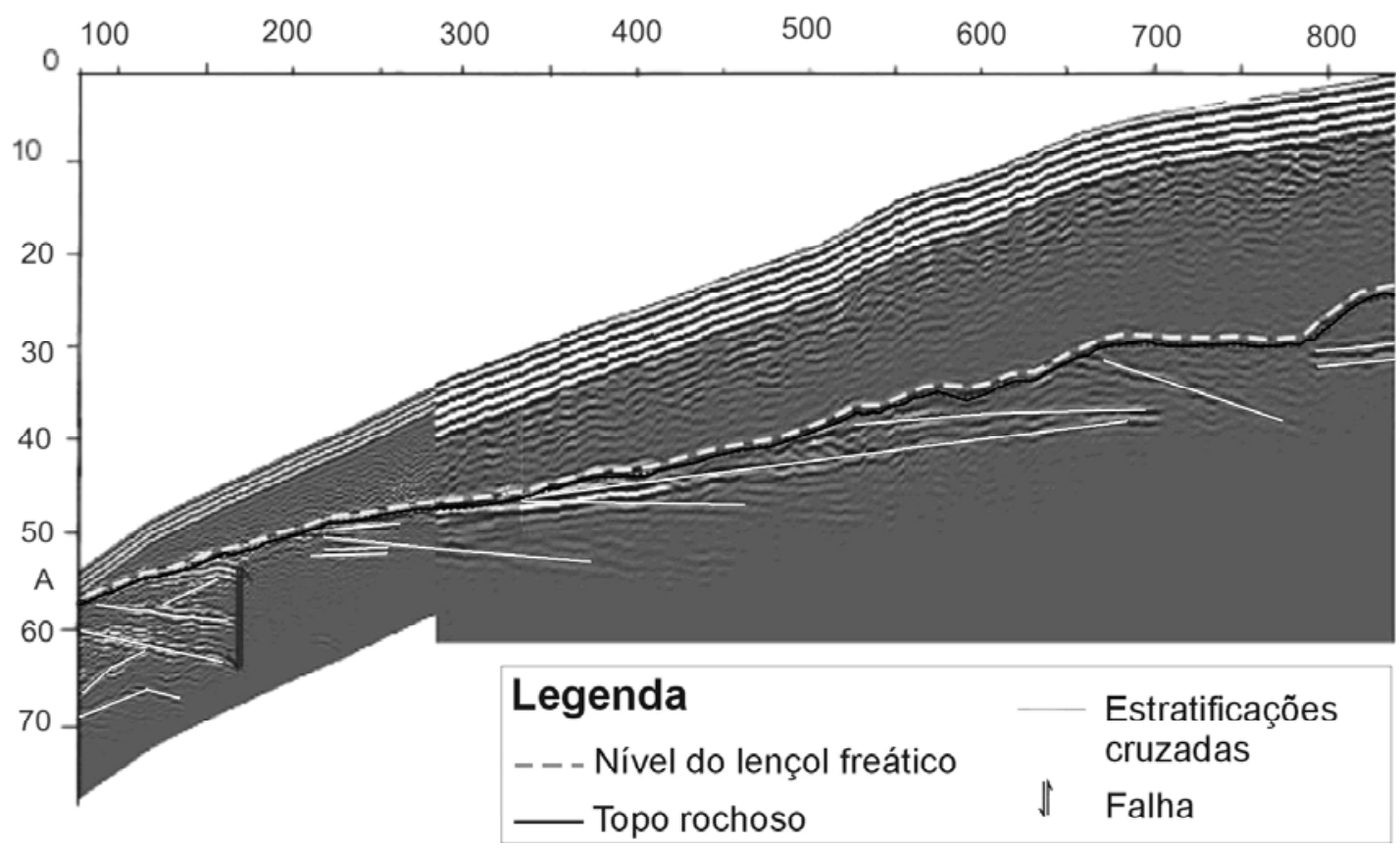

Figura 13 Seções geofísicas com GPR, freqüência composta de 100 e 50 Mhz, jul./2001 (durante estação seca). Fonte: SHIRAIWA e MOURA (2002).

Os dados de eletroresistividade mostram que a seção geoelétrica agrupada apresenta cinco camadas definidas com base nas resistividades aparentes, as quais foram também correlacionadas às descrições das amostras a trado, das trincheiras e exposição de solo e rocha nos taludes da voçoroca Paraíso (CASTRO, 2002): (1) oscilando entre 35551 e 98937 ohm.m, correspondem ao solo arenoso cinza orgânico; (2) oscilando entre 98070 e 6388 ohm.m, correlacionado a solo constituído por areia fina com cerca de 90\% de quartzo; (3) oscilando entre 1175 a 16936 ohm.m, correspondem ao arenito fino apresentando níveis de arenito conglomerático laterizado, no ponto da SEV-S2, posição de 730 m, ocorre redução na espessura, sugerindo descontinuidade; (4) oscilando entre 100 e 839 ohm.m, correspondem ao arenito fino, exceto nas posições referentes as SEV-S10 e SEV-S13 que apresentam valores de 5136 a 10887 ohm.m, respectivamente, sugerindo falha; (5) oscilando entre 1186 a 93424 ohm.m, onde 0 maior valor é observado para a SEV-S10, desaparecendo na SEV-S13 e reaparecendo nas SEV-S6 e SEV-S4 com valores de resistividade oscilando de 1186 a 1727 ohm.m, camada não alcançada pela SEV-S2.

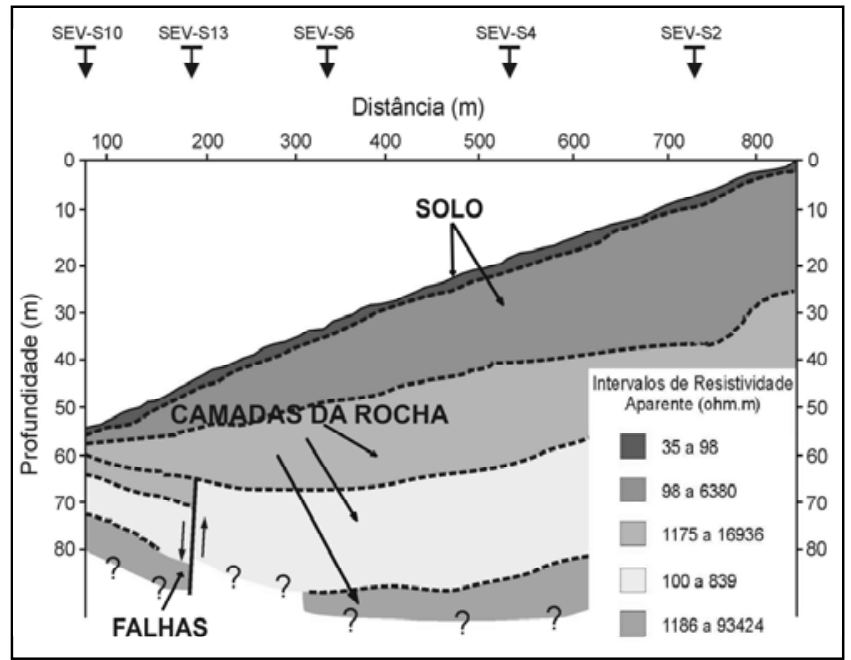

Figura 14 Seção geoelétrica agrupada, elaborada com os dados de Sondagem Elétrica Vertical, na linha da toposseqüência. Fonte: SHIRAIWA e MOURA (2002). 
A superfície piezométrica aprofunda-se à medida que aumenta a cota na vertente, variando de 2,35 no fundo do vale (posição $80 \mathrm{~m}$ ) a $26 \mathrm{~m}$ no topo da vertente (posição $730 \mathrm{~m}$ ). A diferença de profundidade do lençol freático é $22,5 \mathrm{~m}$, entre a SEV-S10 e a SEV-S2, sugerindo uma superfície quase horizontal durante a estiagem. Na posição de $150 \mathrm{~m}$, na seção de GPR, observa-se também uma interrupção brusca nas camadas sugerindo uma falha normal, como confirmado pela SEV e, na posição 680 a $780 \mathrm{~m}$, uma descontinuidade sub-horizontal que poderia induzir instalação de piping. Pode-se deduzir que não há variação notável do nível freático do topo até o terço inferior da vertente, dando-se 0 inverso nesta posição. Porém, como os dados, por limitações do método, não cobriram o setor basal, onde se identificou 0 depósito supostamente de origem aluvial (também constatado na voçoroca Chitolina), os mesmos foram descritos e desenhados na voçoroca vizinha (Paraíso) e em outra maior próxima.
As duas voçorocas descritas e analisadas por REZENDE (2003) mostraram direções estruturais visíveis e coincidentes nos seus taludes, seja no saprólito do arenito, seja nos solos ou depósitos basais, com direções NW-SE, dominantes na área e na região. $O$ nivel turfoso foi seccionado pela voçoroca, cujo freático livre e rebaixado corre já no arenito alterado e, acima deste, encontra-se pacote sedimentar argiloso e arenoso alternado esbranquiçado preenchendo concavidade pré-existente e em condições de saturação permanente, tal como constatado na toposseqüência, encimados por uma capa de laterita também cortada, acima da qual encontra-se a turfa. Com isto corrobora-se a interpretação de depósito aluvial anterior à voçoroca submetido a ambiente de saturação, similar ao observado no caso da Chitolina (BOULET, 2001). Acima do nível turfoso, o espesso depósito arenoso fino esbranquiçado de até $5 \mathrm{~m}$ com características do arenito Botucatu, embora intensamente lavado, sugere depósito da descarga proveniente da própria voçoroca (Fig. 15).

A

1 - Areia marrom amarelada com grânulos arredondados de feldspato, fragmentos de rocha (arenito) e presença de planos preenchidos de ferro (couraça)

2 - Argila arenosa bruno pálida, friável, pouco plástica, pouco úmida

3 - Argila arenosa cinza escura, maciça, pouco plástica

4 - Turfa

5 - Argila cinza clara, mole e plástica, com fragmentos de galhos e folhas, saturado

6 - Areia argilosa cinza clara, pouco plástica, com fragmentos de galhos e folhas, saturado

7 - Areia cinza escura, saturado

8 - Areia cinza clara, saturado

9 - Areia branca, saturado

10 - Areia branco amarelada, saturado

11 - Saprólito de arenito, úmido

12 - Solo Areia Quartzosa (não hidromórfica)

ST1... - Sondagem a trado

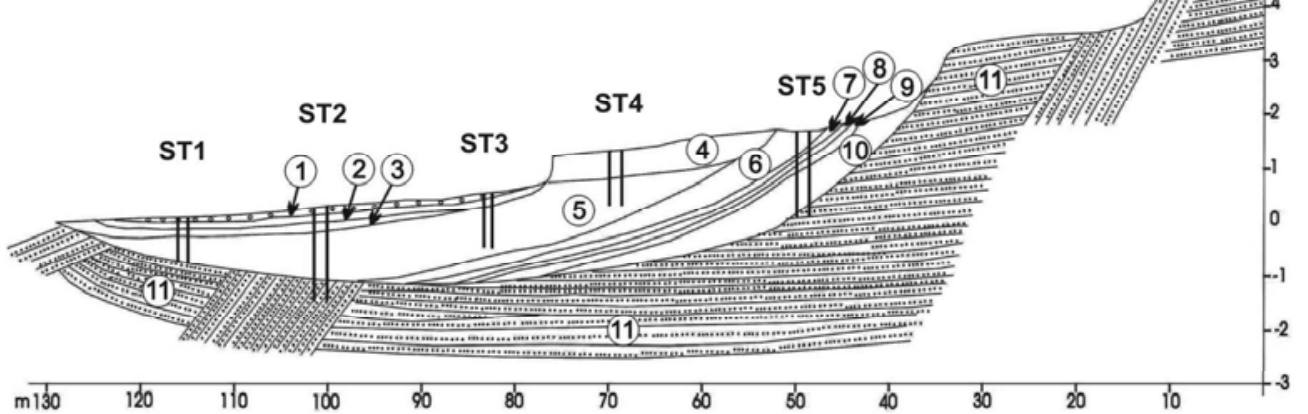

Figura 15 Perfil longitudinal da voçoroca Paraíso mostrando os depósitos basais. Fonte: REZENDE (2003).

Entretanto, como o arenito Botucatu e solos derivados dominam a área, sendo, portanto, fonte tanto de depósitos aluviais como coluviais, como de descargas de voçorocas, e 0 fato das camadas revelarem configuração embaciada, embora ligeiramente discordantes, pode-se supor também contribuição aluvial, portanto, de origem possivelmente mista (alúvio-coluvial). 
O que chama a atenção e motiva estudos geológicos, sedimentológicos e geomorfológicos específicos e ultradetalhados futuros, é que a concavidade basal onde se aloja 0 Gleissolo é pré-existente, de natureza aluvial e conta com argila branca, não compatível inteiramente com o arenito Botucatu. Tais depósitos não são raros e muitos deles levaram alguns autores a interpretá-los como reativação de antigas voçorocas cujas turfas se desenvolvem em níveis escalonados, entre 3 a 30 mil anos atrás (BACELLAR, 2000). 0 fato mais importante é que essas áreas são de risco à instalação do processo de voçorocamento, quaisquer que sejam as origens e idades.

\section{Conclusões}

O processo de voçorocamento é fortemente condicionado pela suscetibilidade dos solos e do relevo, particularmente em zonas concavizadas com declividades de até 8 a 12\% e também por direções estruturais dominantes ligadas ao acamamento e ao sistema de fraturas, tanto em seu surgimento quanto em sua evolução, pois favorecem fluxos hídricos superficiais e subsuperficiais concentrados e convergentes para a base das vertentes.

Não há variação sazonal significativa do nível freático nos terços médio e superior das vertentes, mas na estação chuvosa, o segmento inferior do lençol responde rapidamente, em razão da alta condutividade hidráulica dos solos, da sua pouca espessura e da proximidade do nível de base local.

As taxas de infiltração e a condutividade hidráulica saturada podem ser reduzidas no horizonte superficial do solo, seja por perda de matéria orgânica e reacomodação das partículas de areia, seja por concentração de fluxos em trilheiros, caminhos, estradas vicinais, cercas e valas, induzindo escoamento superficial que origina sulcos e ravinas.

Quando a vertente é desmatada e substituída por pastagem, como ocorrido, a porção jusante das vertentes favorece ainda mais a instalação do fenômeno erosivo associado a piping em zonas de fraqueza, dada a alimentação rápida do lençol. Neste caso, o nível freático raso pode ser facilmente interceptado por fluxos superficiais relacionados ou não a ravinas, facilitando a sua descompressão e liberação, o que aumenta 0 gradiente hidráulico e favorece a remoção de partículas e 0 estabelecimento de fluxos rápidos, de alto poder erosivo. Com chuvas muito intensas ou descarga de sedimentos que promovam uma eventual subida do nível de base local, as zonas de convergência de fluxos subsuperficiais podem remontar a vertente, ampliando a área de risco ligada à estação chuvosa.

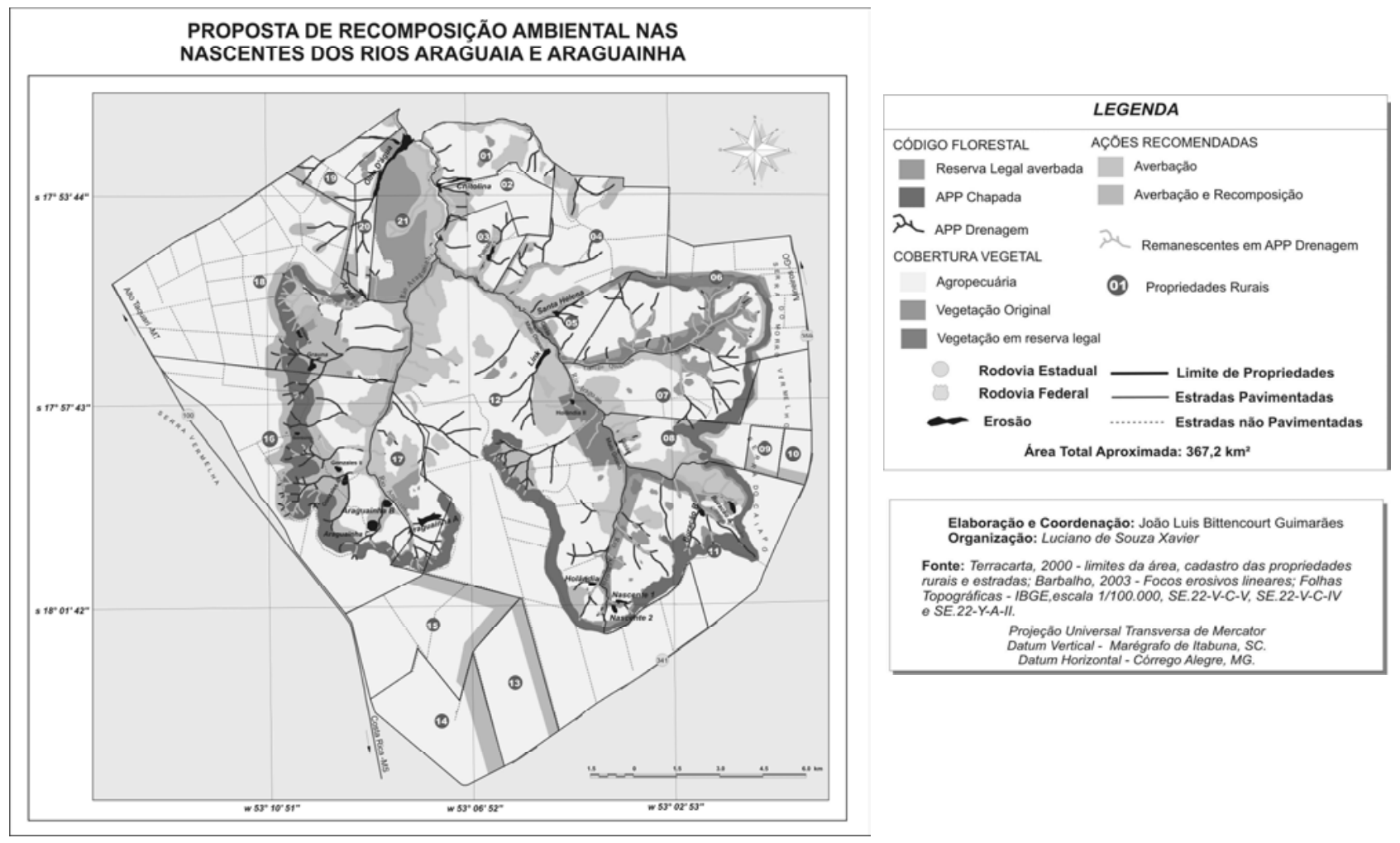

Figura 16 Proposta de recomposição ambiental das Nascentes dos rios Araguaia e Araguainha. Fonte: CASTRO, XAVIER e MACEDO (inédito). 
Os fluxos concentrados e de alto poder erosivo induzem uma aceleração do processo morfogenético de dissecação erosiva linear complexa, o qual se torna acelerado e remontante na vertente nos primeiros anos. Um novo perfil de equilíbrio é alcançado via descarga de sedimentos na base, o que freqüentemente acontece apenas quando, regressivamente, 0 voçorocamento atinge 0 divisor, resultando em grandes pacotes de sedimentos a jusante.

Constataram-se dois pacotes de camadas sedimentares recentes nos casos estudados, um, abaixo do nível orgânico dos Gleissolos, de origem aluvial, em ambiente saturado, preenchendo concavidade pretérita e outro, sobreposto a este, possivelmente resultante da descarga das voçorocas ou de origem mista (alúvio-coluvial). Ambos podem ser seccionados pela voçoroca atual, admitindo-se a hipótese de ciclos de corte e preenchimento, relacionados principalmente à estação chuvosa.

O desenvolvimento das voçorocas é produto de uma dinâmica pedohidrológica complexa multifatorial. Admite-se a possibilidade de reativação e há evidências fortes de controle litoestrutural, o que significa que nem todos os segmentos finais das vertentes sejam suscetíveis ao fenômeno. Isto corrobora os estudos geoambientais de risco, que atribuíram maior probabilidade de ravinas do que voçorocas. Mas, face ao manejo inadequado, as voçorocas podem ter sido induzidas por ravinas que interceptaram o nível freático raso ou mesmo aflorante.

A zona de risco ao fenômeno erosivo de tipo voçoroca inicia-se no limite superior dos Neossolos Quartzarênicos Hidromórficos rasos que corresponde ao máximo de propagação remontante das zonas de convergência de fluxos superficiais e, sobretudo, subsuperficiais. Esse limite, se bem manejado, pode evitar ou até desacelerar processos pequenos já instalados. Se essa zona já é essencialmente de risco, implica na sua incompatibilidade de uso.

\section{Proposta de recomposição ambiental da área do segun- do projeto}

A Fig. 16, proposta de recomposição da área das nascentes dos rios Araguaia e Araguainha finalizada por GUIMARÃES (2003), revela os princípios adotados face aos estudos realizados. Nela pode-se observar que há necessidade de restabelecimento de reservas legais e de recomposição das áreas de preservação permanente (bordas de Chapada, escarpas, fundos de vale e cabeceiras de drenagem) de modo a compor corredores de biodiversidade. Paralelamente, pode-se observar também a necessidade de regularização de áreas e de implementação de práticas conservacionistas (GUIMARÃES, 2003).

Recomenda-se preservar a cobertura vegetal dos topos e nos fundos de vale e vegetá-los imediatamente se degradados e, em risco máximo ou alto, preferencialmente com plantas nativas de crescimento rápido, além de densa cobertura e enraizamento, por toda a faixa de risco. Recomenda-se conter 0 avanço das voçorocas existentes com obras que privilegiem 0 controle dos fluxos hídricos, inclusive das suas áreas de contribuição tendo em vista as áreas de risco a desequilibrios pedohidrológicos. Por fim, recomenda-se também adequação de estradas, cercas de divisa de pastos e de propriedades, além de manejo adequado das pastagens, para evitar a formação de trilheiros. 
CASTRO, S.S. de (2005). Water erosion in upper Araguaia river basin: distribution, controls, origin and actual dynamic. Revista do Departamento de Geografia, n. 17, p. 38-60.

ABSTRACT: This article presents the results from two research programs focusing the water erosion, principally over gullying, developed on South Upper Araguaia River Basin, Central Plateau of Brazil, covered by fragments of savanna biome, one of the planet's hotspots, related to the Northern Plateau from Paraná Sedimentary Basin, located in Goiás and Mato Grosso States, where an intensive and inadequate deforestation of savanna and faults in management practices in the last three decades are done. These studies based on environmental studies in a multi-scale approach, are initiated by general analyze about the distribution of gullies and its relationships with natural controls and land use and management in order to select the most critical areas and develop detailed studies to subside the control planning. The small to big gullies mostly concentrated on hillslopes, predominantly on large catchments areas, frequently following the hollow of heads, or perpendicularly to the bottom of valleys principally in medium and upper basins from tributaries of Araguaia River, are placed in the lower surface related to smoothed interfluves with gentle slopes and fine regolith sandy soils derived from the eolic sandstone of Botucatu Formation, witch involves the high regional surface known as Chapada. Two selected critical areas to pedological and hydrological studies are focused. Detailed observations in toposequence of soils and laboratory analyses of soil samples accomplished by monitoring of rain by pluviometer and rain gauge and water table level monitoring through piezometric and geophysical methods in order to identify the relationships between soils, slope forms, land use and actual physic-hydrological behavior of soils and slopes are done. The conclusions emphasize one hydropedological unbalance related to the natural variables and land use, mainly on the footslopes. The hydrological unbalance is characterized by high hydraulic gradient and a link between the superficial and sub-superficial overflows converging to the saturated zone, principally during the rainy season, which favors the gully process, in a regressive pathway development related to piping land controlled by structural directions. Finally, one example for rehabilitation based on environmental laws, conservational practices and recuperation of legal reserves and permanent preservation of degraded areas is presented.

Key-words: High Araguaia River Basin, gully, natural controls, susceptibility, risks, land use and management, physical-hydrological monitoring, hydropedological unbalance.

Recebido em 7 de setembro de 2005, aceito em 2 de outubro de 2005.

\section{Referências Bibliográficas}

AB'SABER, A.N. (1969). Um conceito de Geomorfologia a serviço das pesquisas sobre o Quaternário. São Paulo: IGEOG-USP Geomorfologia, n. 18, 15p.

ASSAD, M.L.L.; ASSAD, E.D.; EVANGELISTA, B.A. (1994) Chuvas extremas na região dos cerrados. IN: Chuva nos cerrados: análise e espacialização. ASSAD, E.D. (Coord.). Brasilia: EMBRAPA-CPAC: EMBRAPA - SPI.

BACELLAR, L.A. (2000) Condicionantes geológicos, geomorfológicos e geotécnicos dos mecanismos de voçorocamento na bacia do rio Maracujá, Ouro Preto, MG. Universidade Federal do Rio de Janeiro. Tese de Doutorado.

BARBALHO, M.G.S.; CASTRO, S.S.; CAMPOS, A.B.; MEDEIROS, C.M. (2003) Morfologia do relevo e ocorrências erosivas lineares na alta bacia do Rio Araguaia, GO/MT. In: $X$ SBGFA, 2003, Rio de Janeiro. Trabalhos Completos. Anais. CDROM.

BARBALHO, M.G.S.; CASTRO, S.S. (2002) Morfopedologia Aplicada ao Diagnóstico e Diretrizes para o Controle dos Processos Erosivos Lineares na Alta Bacia do Rio Araguaia (GO/MT/MS). SINAGEO, IV, São Luís - MA, Anais Resumos. p. 14-15, Anais Trabalhos Completos CDROM.
BARBALHO, M.G.S.; CASTRO, S.S.; CAMPOS, A.B. (2003) Morfologia do relevo e ocorrências erosivas lineares na alta bacia do rio Araguaia, GO/MT. SBGFA, X, Rio de Janeiro. Anais CDROM.

BARBALHO, M.G. da S.; SILVA, A.A. ; MEDEIROS, C.M.; RAMOS, D.R.; XAVIER, L.S.; PEREZ FILHO, A.; CASTRO, S.S. (2001) Caracterização Geoambiental: Uso e Ocupação das Terras da região do Alto curso do Rio Araguaia (GO/MT). Simpósio Brasileiro de Geografia Física Aplicada, VIII, Recife, Anais CDROM.

BOIN, M.N. (2000). Chuvas e Erosões no Oeste Paulista: uma análise climatológica aplicada. Universidade Estadual Paulista, Rio Claro, SP. 264p. Tese de Doutorado.

BOULET, R. (1988). Análise estrutural da cobertura pedológica e cartografia. In: Congresso Brasileiro de Ciência do Solo, 21, Campinas. Anais... Campinas: SBCS. p. 79-90.

BOULET, R. (2001) Relatório de consultoria referente à primeira fase dos estudos realizados para a recuperação da voçoroca Chitolina, município de Mineiros, 34p.

BRASIL (1974) II Plano Nacional de Desenvolvimento 1975-1979.

Rio de Janeiro: Gráfica da FIBGE, p. 15-145

CAMPOS, A.B.; CASTRO, S.S.; CASSETI, V.; SANTOS, R.; 
MARTINS, M.S.; SILVA, A.A. (2000) Geological and Topographic indicators of the gully erosion at the Upper Araguaia River Basin, Brazil. Int. Symp. On Gully Erosion Under Global Change. Leuven, Bélgica, Abstracts, p. 16-19.

CASTRO, S.S. (1998) Bacia do Alto Araguaia: diagnóstico e prognóstico dos processos erosivos, análise de suas conseqüências e propostas de controle. Projeto de Pesquisa. CONCITEG /SECTEC.

CASTRO, S.S. (1999) Micromorfologia de solos aplicada ao diagnóstico de erosão. In Erosão e Conservação de Solos: conceitos, temas e aplicações. Cap.4 p. 127-163.

CASTRO, S.S. (2000) Diagnóstico, prognóstico e controle de erosões rurais e urbanas nos estados de Mato Grosso e Goiás. Projeto de Pesquisa Edital CNPq/PCOPG.

CASTRO, S.S. (2002a) Diagnóstico, prognóstico e controle de erosões rurais e urbanas nos estados de Mato Grosso e Goiás Relatório Final. CNPq/PCOPG.

CASTRO, S.S. (2002b) Diagnóstico e prognóstico para controle de erosões rurais e urbanas nos estados de Mato Grosso e Goiás Relatório Final. FAPESP, Campinas.

CASTRO, S.S. (2003) Relatório final do Projeto Diagnóstico e prognóstico para controle de erosões rurais e urbanas nos estados de Mato Grosso e Goiás. CNPq/PCOPG, 235 p.

CASTRO, S.S.; BARBALHO, M.G.S.; MARINHO, G.V.; CAMPOS, A.B.; SALOMÃO, F.X.T.; VECHIATTO, A. (2004) Condicionantes hidrológicos, geomorfológicos, pedológicos e de uso e manejo dos solos na circulação hídrica e processos de voçorocamento na alta bacia do rio Araguaia (GO/MT). In: COUTO, E. G.; BUENO, J. F. (Eds.). Os (Des) caminhos do uso da água na agricultura brasileira. Cuiabá: Ed. UFMT/SBCS, p.408-448.

CASTRO, S.S.; CAMPOS, A.B; OLIVEIRA, C.J.; SILVA, A.A. (1999) The upper Araguaia basin and the effects of humaninduced erosion. Int.Symp. of Geomorphology and Paleohydrology of Large Rivers - GLOCOPH/IAG, Bol. Goiano de Geografia, 19 (1):128-139.

CASTRO, S.S.; CAMPOS, A.B.; SILVA, A.A.; SANTOS, R.; MARTINS, M.S. (2000) Condicionantes morfopedológicos dos processos erosivos lineares na bacia do alto Araguaia (GO , MT). SINAGEO, 3, Campinas, Anais Resumos: p. 115.

CASTRO, S.S.; SALOMÃO, F.X. de T. (2000) Compartimentação morfopedológica e sua aplicação. São Paulo, SP: GEOUSP, 7.

CASTRO, S.S.; XAVIER, L.S.; BARBALHO, M.G.S. (2004) Atlas
Geoambiental das Nascentes do rio Araguaia e Araguainha. SEMARH-GO. Projeto de Recomposição Ambiental das Nascentes do Araguaia. Goiânia.

CASTRO, S.S.; XAVIER, L.S. (2004) Plano de controle de erosão linear das nascentes dos rios Araguaia e Araguainha. SEMARH-GO. Projeto de Recomposição Ambiental das Nascentes do Araguaia. Goiânia (no prelo).

CASTRO, S.S.; COOPER, M.; SANTOS, M.C.; VIDALTORRADO, P. (2003) Micromorfologia de solos: bases e aplicações. In: Tópicos em Ciência do Solo, 3, SBCS, Viçosa, v. 3: 107-164.

CENTRAIS ELÉTRICAS DE GOIÁS - CELG (1998) Levantamento de campo para elaboração de projeto de recuperação das voçorocas. Rel. Técnico final do Projeto recuperação Ambiental das Nascentes do Araguaia.

DAEE; IPT (1989) Controle de erosão: bases conceituais e técnicas; diretrizes para o planejamento urbano e regional; orientações para o controle de boçorocas urbanas. São Paulo: Secr. de En. e San.- Departamento de Águas e Energia Elétrica. $92 \mathrm{p}$.

DE BIASI, M. (1992) Carta clinográfica: os métodos de representação e sua confecção. São Paulo, Revista do Depto. de Geografia, USP, 5: 45-60.

EMPRAPA (1999) Sistema Brasileiro de Classificação de Solos. Brasília, Centro Nacional de Pesquisa de Solos, EMPRAPA .

FRANCO, M.S.M.; PINHEIRO, R. (1982) Geomorfologia In Projeto RADAMBRASIL 27, Rio de Janeiro.

FARIA, A.R. (2001) Uso do solo na bacia do alto rio Araguaia estados de GO e MT: revisão sobre a importância e mapeamento atual. Monografia. IESA/UFG, Goiânia.

FUNDAÇÃO EMAS (1998a) Cumeeira do Brasil: projetos de preservação ambiental. Brasília: ABEAS, $106 \mathrm{p}$.

FUNDAÇÃO EMAS (1998b) Projeto Recomposição Ambiental das Nascentes do Araguaia, Mineiros, $4 \mathrm{p}$.

GOEDERT, W.J.; WAGNER, E. (2004) O planejamento de uso do solo enfocando a conservação do solo e da água: a experiência no Cerrado. In COUTO, E.G.; BUENO, J.F. (Eds.). Os (Des) caminhos do uso da água na agricultura brasileira. Cuiabá: Ed. UFMT/SBCS, p.425-454.

GOMES, M.A.F.; COUTINHO, H.L.C.; CERDEIRA, A.L.; LUCHIARI Jr, A. (1999) Uso agrícola de áreas de recarga do aqǘfero Botucatu (Guarani) localizadas na porção noroeste e parte oeste da Bacia Sedimentar do Paraná. Jaguariúna: EMBRAPA MEIO AMBIENTE, Documentos 8, 27p. 
GOMES, M.A.F.; CERDEIRA, A.L.; FILIZOLA, H.F. (1999) Reconhecimento de áreas potencialmente críticas na região do Alto Taquari e Coxim (MS): subsídio à caracterização dos impactos decorrentes das atividades agrícolas. Jaguariúna: EMBRAPA MEIO AMBIENTE, Documentos 15, 28p.

GOMES, M.A.F; FILIZOLA, H.F.; PAULA, M.M.; DIOGO, A.; CERDEIRA, A.L. (2000) Áreas críticas na porção de recarga do aqüifero Guarani localizadas nas nascentes do rio Araguaia. Ja-guariúna: EMBRAPA MEIO AMBIENTE, Documentos 18, $16 p$.

GOMES, H.; TEIXEIRA NETO, A. (2004) Geografia Goiás-Tocantins. 1. ed. Goiânia: CEGRAF/UFG. 1993. 227 p.

GUIMARÃES, J.L.B. (2003) Proposta de Recomposição e Averbação das Reservas Legais e Áreas de Preservação Permanente da Região das Nascentes do Araguaia. Rel. Técnico. Fundação $O$ Boticário de Proteção à Natureza

IANHEZ, A.C. et al. (1983) Geologia. In: Projeto RADAMBRASIL. Folha SE 22, Goiânia. Rio de Janeiro, Rel. no. 31: 23-348.

IPT (1986) Orientações para o combate à erosão no Estado de São Paulo, Bacia do Peixe - Paranapanema. Rel. Técnico 24.739, São Paulo.

IPT; METAIS DE GOIÁS (1998) Investigação, caracterização da fenomenologia e diretrizes para o controle corretivo e preventivo de nove feições erosivas lineares e respectivas bacias de contribuição, Bacia do Alto Araguaia, GO/MT. Relatório Técnico 36. 904, 90p.

LEPSCH, I.F.; BELLINAZZI, J.; BERTOLINI, D.; ESPINDOLA, C.R. (1983) Manual para levantamento utilitário do meio físico e classificação de terras no sistema de capacidade de uso. Campinas: Sociedade Brasileira de Ciência do Solo.

LIBAULT, A. (1968) Geocartografia. São Paulo, EDUSP.

MAMEDE, L.; ROSS, J.S.; SANTOS, L.M.; NASCIMENTO, M.A.L.S. (1983). Geomorfologia. In: Projeto RADAMBRASIL, Folha SD.22, Goiânia. Rio de Janeiro: Levantamento de Recursos Naturais 31: 349-412.

MARINHO, G.V.; CASTRO, S.S. (2002) Caracterização FísicoHídrica e da Suscetibilidade Erosiva Linear na Sub-bacia do Córrego Queixada, Alta Bacia do Rio Araguaia-GO. SINAGEO, IV, São Luís - MA. Anais Resumos, p. 59-60 e Anais CDROM.

MARINHO, G.V.; CASTRO, S.S. (2003) Estudo de piezometria com ênfase aos processos de voçorocamento na alta bacia do rio Araguaia/GO. In: CBCS, XXIX, SBCS Ribeirão Preto. Anais CDROM.
MARTINS, M.S. (2000) Substrato geológico e sua relação com as ocorrências erosivas lineares na Bacia do Rio Araguaia e Rio Babilônia. Mon. de final de curso de Graduação em Geografia. IESA/UFG, Goiânia: 134 p.

MEDEIROS, C.M.; CASTRO, S.S. (2002) Estrutura Fundiária, Uso do Solo e Erosão na Alta Bacia do Rio Araguaia. Encontro Nacional de Geógrafos AGB, João Pessoa-PB, Anais.

NIMER, E. (1989) Clima. In: Geografia do Brasil - Região CentroOeste. Vol. 1, IBGE. Rio de Janeiro.

NOVAES, A.S.S.; AMARAL, F.O.; VIEIRA, P.C.; FRAGA, A.G.C. (1983) Levantamento Exploratório dos Solos. In: Projeto RADAMBRASIL, Folha SE22, Goiania. Rio de Janeiro. Levantamento de Recursos Naturais, 31: 413-576

OLIVEIRA, C.J.F. (1999) A suscetibilidade dos solos aos processos erosivos lineares nas sas sub-bacias do Alto Rio Araguaia e Rio Babilônia. Monografia de fim de curso, IESA/UFG, Goiânia,.

OLIVEIRA, V.C.B.; CASTRO, .S.S. (2005) Susceptibility and risks to laminar erosion by runoff in the south of Araguaia river basin, Brazil. In: International Symposium on Land degradation and Desertification, Actes. Uberlândia: Sociedade e Natureza, Sp. Issue,: 697-708.CDROM.

OLIVEIRA, A.M.S.; SALOMÃO, F.X.T. (1992). Erosão e assoreamento. In: Tecnologia, ambiente e desenvolvimento. São Paulo: IPT. p. 47-54.

RAMALHO FILHO, J.; BEEK, K.J. (1995) Sistema de avaliação da aptidão agrícola das terras. 3ed., Rio de Janeiro: Embrapa, 65p.

REICHARDT, K. (1987) A água em sistema agrícolas. São Paulo, Ed. Manole Ltda., $188 \mathrm{p}$.

RAMOS. D.S.; CASTRO, S.S. (2003) Análise Preliminar da Intensidade e Duração das Pluviosidades na Alta Bacia do Rio Araguaia nos Estados de Goiás e Mato Grosso. Anais do V Simpósio Brasileiro de Climatologia Geográfica, Curitiba.

RAMOS, D.M.R.; XAVIER, L.C.; CAMPOS, A.B.; LUIZ, G.C. (2001) Análise frequencial e pentadial e dos totais pluviométricos e suas influências no desenvolvimento dos processos erosivos lineares na alta bacia do rio AraguaiaGO. Goiânia: VII SNCE, Anais CDROM, 9p.

REICHARDT, K. (1987) $A$ água nos sistemas agrícolas. São Paulo: Manole Ltda.,188 p.

REZENDE, A. (2003) Condicionante geológico do mecanismo de voçorocamento da voçoroca Paraíso na sub-bacia do córrego Capivara (bacia do alto Araguaia) - Mineiros. GO. 
Dissertação de Mestrado IESA/UFG.

SALOMÃO, F.X. de T. (1999) Controle e prevenção dos processos erosivos. In: GUERRA, A.J.T. et al. (Orgs.) Erosão e conservação dos solos: conceitos, temas e aplicações. Rio de Janeiro: Bertrand Brasil.

SANTOS, R.R. (2001) Condicionantes morfométricos topográficos das vertentes e sua importância nos processos pluvioerosivos na alta bacia do rio Araguaia. Monografia IESA/UFG, Goiânia.

SILVA, A.S.; BARBALHO, M.G.S.; CASTRO, S.S. (2001) Análise comparada de formas de ocorrências erosivas lineares utilizando diferentes resoluções com imagem Landsat TM $5 \mathrm{e}$ 7. Anais do IX Simpósio Brasileiro de Geografia Física Aplicada, Recife.

SILVA, A.A. (2000) Estudo das relações entre o sistema viário, a rede de drenagem e as características erosivas lineares na Bacia do Alto Rio Araguaia. Monografia de conclusão de curso IESA/UFG, Goiânia.

SOARES, P.C.; FIORI, D.P. (1976) Lógica e Sistemática de Análise e Interpretação de Fotografia Aérea em Geologia. Notícia Geomorfológica, n. 16 (32), 71-104.

TERRACARTA (2000 e 2001). Relatórios Técnicos: Planimetria, Cartografia, Cadastro rural, Pluviometria, Solos da Erosão Chitolina. Goiânia, 230p.

XAVIER, L.S.; CASTRO, S.S. (2005) Linear erosion in the region of source área of Araguaia River: conditionings and corrective and preventive control. Int. Symp. Land Degradation and Desertification, Actes. Uberlândia: Sociedade e Natureza Sp. Issue, 182-191. 